\title{
Uluslararası Gelişmeler Işığında Türkiye-Mısır İlişkileri
}

(1945-1960)

N.Neşe KEMÍKSİZ *

Öz

Türkiye’nin, jeopolitik önemi nedeniyle Ortadoğu'da her zaman dikkate alması gereken Misır ile ilişkileri; tarihi bağlar, rejim farklılıkları, farklı dış politik yönelimler nedeniyle diplomatik ilişkilerin kurulduğu 1926’dan beri inişli çıkışlı bir seyir izlemiștir. İkinci Dünya Savaşı́ndan sonra Sovyetler Birliği’nin Türkiyeden Boğazlarda üs ve Doğu sınırlarında değişiklik talepleri, Türkiye’yi Batı ile ittifak arayışlarına yöneltmiștir. Mısır ise savaş sonrasında ülkesindeki İngiliz askeri mevcudiyetine son verme mücadelesi içerisindedir. İngiltere’nin Ortadoğu'daki stratejik çıarlarını korumak için Süveyş̧ten çlkmak istememesi ve bölgesel bir savunma düzeni oluşturarak Türkiye’yi de buraya dahil etme girişimleri, 1950'li yıllardan itibaren Türkiye-Mısır ilișkilerini etkilemeye başlamıștır. 1948'de İsrail'in kurulması ve Arap-İsrail savaşındaki Arap yenilgisinin yol açtığı bölgesel ortamda Mısır lideri Albay Abdülnasır, karizmatik kişiliği, Batı emperyalizmine ve İsrail’e karşı güçlü söylemleriyle Arap milliyetçiliğine hız kazandıracaktır. Bu dönemde kurulan Bağdat Paktı, Türkiye-Mısır ilişkilerinde sorunlara neden olacaktır. Türkiye, Bağdat Paktı’nı Sovyetler Birliğı’nin bölgeye girmesini önleyecek bir oluşum olarak görürken, Nasır, Paktın Batı emperyalizminin bölgedeki mevcudiyetini sürdürmek için kurulduğunu düşünmektedir. Türkiye’nin bölgedeki gelişmelere Soğuk Savaş perspektifinden yaklaşması, Türkiye ile Mısır’’ tüm bölgesel krizlerde karşı karşıya getirecektir. Çalışmanın amacı, 1945-1960 arasındaki uluslararası gelişmelerin Türkiye-Mısır ilişkileri ve Türkiyẻnin Ortadoğu politikası üzerindeki etkilerini ortaya koymaktır.

Anahtar Sözcükler: Mısır, Nasır, Süveyş Krizi, Arap Milliyetçiliği, Bağdat Paktı Jel Kodu: F50

\section{Turkey-Egypt Relations in the Light of the International Events} (1945-1960)

\begin{abstract}
Turkey's relations with Egypt to which Turkey should always pay utmost regard in terms of relations in the Middle East because of its geopolitical importance, have experienced ups and downs since 1926, in which the diplomatic relations were formed, due to the historical bounds, regime differences and different foreign policy trends. After the Second World War, Soviet Union's demands pertaining to bases on the Straits and changes on the Eastern Borders from Turkey prompted Turkey to search for Alliance with West. Egypt was in the pursuit of terminating the presence of British soldiers in their country after the War. Since 1950s, relations between Turkey and Egypt have been affected by Britain unwilling to leave Suez to protect its strategical interest in the Middle East and by its attempts to form a regional defense organization and to include Turkey therein. Egyptian Leader, Colonel Abd el Nasser, accelerated the Arabian nationalism in the regional environment caused by the foundation
\end{abstract}

* Dr., Anka Enstitüsü Bilimsel Danışma Kurulu Üyesi,

ORCID ID: 0000-0003-2622-3977 n.kemiksiz@ankaenstitusu.com 
of Israel in 1948 and the Arabian defeat in the Arab-Israel War with his charismatic character and powerful discourses against Western imperialism and Israel. Establishment of Baghdad Pact in this period caused problems in Turkey-Egypt relations. While Turkey considered Baghdad Pact as a formation that would prevent Soviet Union from interfering in the region, Nasser thought that the Pact was established to maintain the Western imperialism in the region. Turkey's Cold War-perspective approach to the events in the region caused conflict between Turkey and Egypt in all regional crises. Aim of this study is to reveal of the international events between 1945 and 1960 on Turkey-Egypt relations and Turkey's Middle East policy.

Keywords: Egypt, Nasser, Suez Crisis, Arab Nationalism, Baghdad Pact

Jel Code: F50

\section{GíRiş}

Mısır; Asya ile Afrika, Kızıldeniz ile Akdeniz arasında yer alan coğrafi konumu, büyüklüğü, nüfusu, kültürel zenginliği ve devlet geleneği nedeniyle jeopolitik önem taşıyan ve Türkiye bakımından Ortadoğu'da her zaman dikkate alınması gereken bir ülke olmuştur. İki ülke arasında tarihi bağlardan, rejim farklılıklarından, farklı dış politik yönelimlerden kaynaklanan sorunlar, ilişkilerin inişli çıkışlı bir seyir izlemesine yol açmıştır. Mısır’ın bölgesel liderlik iddiası, ikili ilişkileri olduğu kadar, Türkiye’nin bölge ülkeleri ile ilişkilerini de etkilemiştir. Bu etki, özellikle Nasır döneminde kendisini hissettirmiştir.

Diplomatik ilişkilerin kurulduğu 1926'dan İkinci Dünya Savaşı’na kadar olan dönemde Türkiye-Mısır ilişkileri; hilafetin kaldırılmasının Mısır kamuoyunda yarattığı tepkiler, Cumhuriyet karşıtlarının Mısır'da barınma ve faaliyet gösterme imkanı bulmaları, Türkiye’nin afyon üretiminden kaynaklanan sorunlar, Mısır'daki Türk vatandaşlarının karşılaştı ğ 1 adli problemler gibi ikili sorunlar çerçevesinde şekillenmiştir². Mısır'ın Ankara Elçisi'nin 1932'deki 29 Ekim Resepsiyonu'na fesiyle katılmasının yol açtığ 1 diplomatik kriz ise ilişkilerde ciddi gerginliğe neden olmuştur³ ${ }^{3}$. 1935'te İtalya’nın Habeşistan’ı işgal etmesi üzerine ilişkilerde yumuşama başlamış, Mısır'ın 1936'da İngiltere ile imzaladığ 1 İttifak Antlaşması'yla tam bağımsızlığına kavuşmasından sonra Milletler Cemiyeti’ne girme isteğine Türkiye tam destek vermiştir ${ }^{4}$. İki ülke arasında Nisan 1937'de Dostluk Antlaşması ile birlikte bir İkamet Anlaşması ve Tabiiyet Sözleşmesi imzalanmıştır ${ }^{5}$. İkinci Dünya Savaşı'na kadar olan dönemde bu ortak tehdit algısından kaynaklanan yumuşama havası devam etmiştir.

İkinci Dünya Savaşı’ndan sonra $\mathrm{ABD}$ ve Sovyetler Birliği’nin hakim güçler oldukları

2- Semih Bulut, "Atatürk Dönemi Türkiye-Mısır İlişkileri (1926-1938)", Atatürk Araştırma Merkezi Dergisi, C.XXVI, S.78, s.540-543.

3- Fes olayı ile ilgili detaylı bilgiler için Bkz: Bilal Şimşir, "Fes Olayı: Türkiye-Mısır İlişkilerinden Bir Sayfa (19321933)", TTK Belleten, C.48, S. 189-190, Ocak-Nisan 1984, ss.1-87

4- Esra Sarıkoyuncu Değerli, “Türk-Mısır Siyasi ve Kültürel İlişkileri (1923-1938)”, Yeni Türkiye, Ortadoğu Özel Sayıs1, C.V, S. 86, Ocak-Haziran 2016, s.31.

5- Bulut, a.g.m., s.546. 
yeni bir dünya düzeni oluşmaya başlamış, Türkiye bu dönemde Sovyetler Birliği'nin Doğu sınırları ve Boğazlar ile ilgili talepleri ile karşılaşmıştır. Türk-Sovyet sınırındaki "haksızlıkların” giderilmesi gerektiği ve Boğazları savunma konusunda Türkiye'nin ehliyet ve imkanlarından emin olunamadığı belirtilerek gündeme getirilen Sovyet talepleri, Türkiye'nin Sovyetler Birliği'nden tehdit algılamasına neden olmuştur ${ }^{6}$. Misır, savaş sırasında İngiltere’nin Akdeniz üssü olmanın yol açtığ 1 sosyal ve ekonomik sıkıntıları yaşamakta, ülkedeki İngiliz askeri mevcudiyetinin sona ermesini, İngiliz askerlerinin çekilmesini talep etmektedir. İngiltere ise Ortadoğu'daki güç boşluğunun Sovyetler Birliği tarafından doldurulabileceği ve stratejik çıkarlarının tehlikeye gireceği düşüncesiyle bölgeden çekilmek istememektedir. İngiltere’nin, içinde Türkiye’nin de yer aldı̆̆ 1 bölgesel savunma oluşumlarıyla Süveyş’te kalma arayışları, İngiltere-Mısır ilişkilerini olduğu gibi, Türkiye-Mısır ilişkilerini de olumsuz etkileyecektir.

1948'de İsrail'in kurulması ve Arap-İsrail Savaşı, Arap ülkeleri için İsrail'i öncelikli tehdit haline getirirken, silah taleplerinin Batılı ülkeler tarafından karşılanmaması, 1950’li yıllardan itibaren İsrail'e karşı politikasını sertleştiren ve Arap davasının savunucusu haline gelen Sovyetler Birliği’ni bir seçenek olarak görmelerine yol açacaktır. Arap ülkeleri Sovyetler Birliğìni tehdit olarak değil, davalarına destek olacak bir güç olarak kabul etmektedir. Bu nedenle Batılılar tarafından Sovyet tehdidine karşı gündeme getirilen bölgesel savunma örgütlerinde yer almayı reddedecek, bu oluşumlar içinde yer alan Türkiye'yi de Batılı emperyalistlerin işbirlikçisi olarak göreceklerdir. Türkiye’nin İsrail ile ilişkileri de bu olumsuz bakış açısını pekiştirecektir. ABD’nin Sovyetler Birliği’nin yayılmasını önlemek amacıyla ortaya attığı Kuzey Kuşağı projesinin Ortadoğu’yu da kapsaması düşüncesi, Türkiye’de memnuniyet yaratırken, Arap ülkelerini kendi liderliği altında birleştirmek isteyen Mısır'da tepkiyle karşılanacaktır7 . Nitekim, 1955’te Bağdat Paktı'nın kurulmasıyla birlikte Türkiye’nin Mısır başta olmak üzere Arap ülkeleriyle ilişkilerinde ciddi sıkıntılar yaşanacaktır. Bunda, Mısır’ın Arap dünyasındaki bölünmeden ve liderliğinin sarsılmasından olduğu kadar, İngiltere’nin bölgedeki mevcudiyetini sürdürmeye kalkışmasından duyduğu hoşnutsuzluğun da rolü vardır . Bağdat Paktı’nın ardından Soğuk Savaş koşullarının daha da ağırlaştırdığı bir bölgesel ortamda art arda yaşanan krizler, Türkiye ve Misır'ı sürekli karşı karşıya getirecektir. Türkiye’nin 1950'den itibaren dış politikasını ABD ile sıkı bir ittifaka ve kutuplaşma anlayışına dayandırması, Mısır'ın ise 1952'den sonra Nasır'ın liderliği altında Arap milliyetçiliğinin, Batı’ya ve İsrail'e karşı Arap mücadelesinin merkezi durumuna gelmesi, iki ülkeyi karşı karşıya getiren nedenlerin başında yer almaktadır.

Diğer yandan Türkiye, İkinci Dünya Savaşı'ndan sonra sömürgelerin self determinasyon hakkına dayanarak bağımsızlıklarını ilan etmelerini ve iki kutuplu uluslararası sistemde

6- T.C. Dışişleri Bakanlığı Araştırma ve Siyaset Planlama Genel Müdürlüğü, Türkiye Dış Politikasında 50 Yıl. İkinci Dünya Savaşı Yilları (1939-1946), Ankara, 1973, s.264-265.

7- Dr. Mithat Atabay, Son Yüzyılda Türkiye ve Ortadoğu, Paradigma Akademi Yayınları, Çanakkale, 2016, s.143. 8- Mehmet Gönlübol vd., Olaylarla Türk Dış Politikası (1919-1973), Ankara Üniversitesi Siyasal Bilgiler Fakültesi Yayınlar1, Ankara, 1982, s.282. 
üçüncü bir kutup oluşturma çabalarını göz ardı ederken ${ }^{9}$, Mısır, Asya ve Afrka çağının başladığını gösterdiği değerlendirilen 1955 Bandung Konferansı'yla birlikte Batı’ya karşı Mısır’a büyük destek sağlayabileceğini düşündügü Üçüncü Dünya ülkeleriyle güç birliği yapmaya yönelmiştir ${ }^{10}$. Mısır, bağlantısızlık hareketinin liderlerinden biri iken, bağımsızlık hareketlerinin hız kazandığı bir dönemde Türkiye; İngiltere'nin Süveyş’ten çekilmesini, "hür dünyanın" savunmasını tehlikeye düşüreceği için doğru bulmuyor, bağlantısızlığın Sovyetler Birliğìnin işine yaradığını ileri sürüyordu.

1945-1960 dönemi Türkiye-Mısır ilişkilerinin ele alındığ 1 çalışmada, uluslararası sistemde meydana gelen köklü değişiklikler ve savaş sonrasının farklı tehdit algıları ile farklı jeopolitik gerçekliklerinin Türkiye ve Mısır’ın dış politik yaklaşımlarındaki belirleyici rolü üzerinde durulmaktadır. Çalışmanın ilk bölümünde bir çeşit geçiş süreci niteliğinde olan 1945-1947 arasındaki gelişmeler ele alınmakta, Türkiye’nin Batı ile ittifak arayışları, bölgesel güvenliğini sağlamaya yönelik girişimleri ve Filistin politikası ile İngiltere-Mısır anlaşmazlıkları incelenmektedir. İsrail devletinin kurulması nedeniyle Arap ülkeleri için kritik bir dönemi teşkil eden 1947-1954 arasındaki gelişmeler ikinci bölümde ele alınmakta, Mısır'da Nasır liderliğindeki darbeden sonra Arap milliyetçiliğinin hız kazanması, Türkiye'nin ABD ile yakınlaşmaya başlayan ilişkilerinin Filistin politikasında ortaya çıkardığı değişiklikler ve Ortadoğu savunmasında yer almasının Mısır ile ilişkilerinde yarattığı sorunlar üzerinde durulmaktadır. 1954-1960 dönemi üç alt başlıkta incelenmekte, bu çerçevede; Bağdat Paktı, Süveyş Krizi ve Eisenhower Doktrini ile Ortadoğu krizleri inceleme konusu yapılmaktadır. Ortadoğu krizleri incelenirken Ürdün krizi, Türkiye-Mısır ilişkilerini de çeşitli şekillerde etkileyen Türkiye-Suriye krizi ve Irak rejiminin devrilmesi ile Lübnan ve Ürdün'e yönelik müdahaleler üzerinde durulmaktadır. 1945-1960 döneminin Türkiye-Mısır ilişkilerinin şekillenmesindeki rolünü ele alan çalışmada, bu dönemi belirleyen uluslararası gelişmelerin ikili ilişkilere yansımaları ve Türkiye’nin 1960'ların ortalarına kadar bölgeden kopmasına neden olan Ortadoğu politikasına etkileri ortaya konacaktır.

\subsection{5-1947 DÖNEMİ}

İkinci Dünya Savaşı, dünya güç dengesinde köklü değişikliklere neden olmuş, ABD ile Sovyetler Birliği’nin uluslararası sistemin yeni belirleyici güçleri olacağı anlaşılmıştır. Bununla birlikte, sistemin ne şekilde kurgulanacağı, Sovyetler Birliği ile savaş sırasındaki işbirliğinin sürdürülüp sürdürülemeyeceği henüz netleşmiş bulunmamakta, en azından ABD bu ülke ile savaş sonrası barış ve güvenliğin temininde işbirliği yapılabileceği ümidini taşımaktadır. ABD’nin bu anlayış içinde olması, ciddi bir Sovyet tehdidi ile karşı karşıya kaldığı 1945 ’te Türkiye’nin destek arayışlarına ilgisiz kalması neticesini doğurmuştur.

9- Melek Fırat ve Ömer Kürkçüoğlu, “Arap Devletleriyle İlişkiler”, Baskın Oran (ed.), Türk Dış Politikası. Kurtuluş Savaşından Bugüne Olgular, Belgeler, Yorumlar, Cilt I: 1919-1980, İletişim Yayınları, İstanbul, 2009, s.615. 10- Tayyar Arı, Geçmişten Günümüze Ortadoğu. Siyaset, Savaşve Diplomasi, Cilt I, MKM Yayınları, Bursa, 2012, s.190-191. 
Sovyet hükümetinin, süresi 7 Kasım 1945’te dolacak olan 17 Aralık 1925 tarihli Türk-Sovyet Dostluk ve Saldırmazlık Antlaşması'nın yenilenmeyeceğini, zira savaş sonrasında ortaya çıkan yeni koşullara uygun olmadığını ve ciddi değişiklikler gerektirdiğini bildiren notası üzerine Türkiye, uygun bir uzlaşma zemini aramış, ancak Antlaşma’nın uzatılması için Türk-Sovyet sınırında Sovyetler Birliği lehine bazı değişiklikler yapılmasının ve Boğazların ortak kontrolü ile Boğazlarda deniz ve kara üsleri verilmesinin istenmesi, uzlaşma zemini olmadığgnı göstermiştir ${ }^{11}$. Türkiye’nin bu talepleri reddetmesi üzerine Sovyetler Birliğginin Türkiye’ye karşı ağır bir siyasi baskı kampanyasına girişmesi, Sovyet basınında Kars ve Ardahan'ın Sovyetler Birliği'ne bırakılması yolunda yayınlar yapılması, Türkiye’nin Sovyet tehdidi karşısında İngiltere ve ABD nezdinde girişimlerde bulunmasına neden olmuştur. Sovyetler Birliği'nin konuyu Potsdam Konferansı'nda da gündeme getirmesi ve ABD Başkanı Truman’ın Boğazlar rejiminde değişiklik yapılabileceğini, toprak taleplerinin ise yalnızca iki ülkeyi ilgilendiren bir mesele olduğunu belirtmesi, Türkiye’nin kaygılarını daha da arttırmıştır ${ }^{12}$. Esasen 1945-1947 arasında Türkiye’nin dış politikada karşı karşıya kaldığı en önemli sorun, savaş sırasında içine düştügüu yalnızlık ve yine savaş sırasında başlamış bulunan Sovyet tehdidinin somut bir biçim alması olmuştur ${ }^{13}$.

Türkiye, gereksindiği desteği sınırlı ölçüde olmakla birlikte İngiltere’den alabilecek, karşıllğında da İngiltere’nin Ortadoğu'da korumaya çalıştığı düzenin sürdürülmesine katkı sağlayacaktır. Bu çerçevede Türkiye, Irak ve Ürdün gibi İngiltere yanlısı ülkelerle ilişkilerini geliştirecektir ${ }^{14}$. Türkiye’nin güney sınırlarında bir güvenlik bölgesi oluşturmayı amaçlaması da bu yakınlaşmada etkili olmuştur. Zira Türkiye; Sovyetler Birliği'nin, Bulgaristan, Yunanistan ve Suriyedeki komünist grupları desteklemek suretiyle dolaylı yoldan da Türkiye’yi baskı altına alarak taleplerini kabule zorlamayı amaçladığı görüşündedir ${ }^{15}$. Bu ortamda Türkiye, bir yandan Batılı ülkeler nezdinde destek arayışlarını sürdürürken öte yandan da Irak ve Ürdün'ün Haşimi yönetimleri ile Mart 1946 ve Ocak 1947'de Dostluk ve İyi Komşuluk Antlaşmaları imzalama yoluna gitmiştir ${ }^{16}$. Türkiye’nin Suriye ile Hatay meselesinden dolayı ilişkilerinin iyi olmaması, ayrıca Sovyetler Birliği'nin Suriye'deki komünist gruplara desteği, Suriye ile böyle bir anlaşma yapılmasına imkan vermemiștir. Irak'ın bu dönemde Kuzey İran'da Sovyet desteğiyle kurulmuş olan Mahabad Kürt Cumhuriyeti ve Molla Mustafa Barzani’ye sağladı̆̆ 1 yardım nedeniyle Sovyetler Birliği'nden tehdit algılaması, Türkiye-Irak anlaşmasının imzalanmasında etkili olan bir diğer faktördür. Öte yandan İngiltere, Türkiye’nin sadece Irak ve Ürdün ile değil, tüm Arap ülkeleri, özellikle kendisi bakımından Süveyş nedeniyle büyük önem taşıyan Mısır ile iyi ilişkiler içinde olmasını desteklediği için Türkiye’nin bu seçici davranışının Arap

11- Gönlübol vd., a.g.e., s.201.

12- A.g.e., s.204.

13- Oral Sander, Türk-Amerikan İlişkileri 1947-1964, İmge Kitabevi Yayınları, Ankara, 2016, s.26.

14- Gencer Özcan, “Türkiye-İsrail İlişkilerinde Dönüşüm: Güvenliğin Ötesi”, TESEV Dış Politika Analiz Serisi 1, Kasım 2005, s.13. tesev.org.tr/wp-content-uploads/2015/11/Turkiye_Israil_Iliskilerinde_Donusum.pdf, (Erişim: 05.08.2019).

15- Mustafa Sttk1 Bilgin, "British Attitude Towards Turkey's Policies in the Middle East (1945-47)", Turkish Yearbook of International Relations, C.33, 2002, s.260.

16- A.g.m., s.258. 
dünyasındaki istikrarsızlığg arttıracağ 1 görüşündeydi' ${ }^{17}$. Nitekim Türkiye’nin bu dönemde Mısır ile de dostluk anlaşması imzalaması gündeme gelmiş ve Mısır'ın 1946 başındaki önerisi Türkiye tarafından olumlu karşılanmış olmakla birlikte, Türkiye’nin İngiltere ile Mısır arasında devam eden Süveyş Kanalı anlaşmazlığında İngiltere’ye yakın bir tutum benimsemesi, Süveyş Kanalı'nda güçlü bir İngiliz mevcudiyetini gerekli görmesi ve Mısır’nn Sovyetler Birliği’ne karşı Kanal'ın güvenliğini sağlayamayacağı görüşünde olması, Misır’ın ulusal çıkarları ile Türkiye ve İngiltere’nin çıkarlarının örtüşmediğini göstermiştir ${ }^{18}$. Türkiye’nin, Mısır’n ulusal egemenlik meselesi olarak gördügü bir soruna Sovyet tehdidi perspektifinden yaklaşması, ilişkilerde ayrışmanın başlangıcı olacaktır.

Sovyetler Birliği’nin; Doğu Avrupadaki yayılmacılığı, İran’ın kuzeyinden çıkmamakta direnmesi ve Yunanistan iç savaşında komünistleri desteklemesi, 1946 başından itibaren ABD’nin Sovyetler Birliği ile işbirliği yapılabileceği anlayışından vazgeçmesine yol açacak, Türkiye'nin güvenlik endişelerine de daha hassasiyetle yaklaşılacaktır ${ }^{19}$.

Sovyetler Birliği’nin İran üzerinden Ortadoğu petrolleri ve Basra Körfezi ile Hint Okyanusu'na, Türkiye üzerinden Boğazlar, Ege Denizi ve Doğu Akdeniz’e ve Yunanistan üzerinden yine Doğu Akdeniz’e yayılma çabası içinde olduğunun değerlendirilmesi, İngiltere’nin hayati ilgi ve çıkar alanlarını ve Rusya'ya karşı 19.yüzyılda en hassas noktalarını oluşturan söz konusu bölgeleri savunmak için harekete geçmesini gerektirmişti ${ }^{20}$.

İngiltere, Birinci Dünya Savaşı’ndan sonra Ortadoğu'daki başlıca hakim güç durumundaydı ve İkinci Dünya Savaşı́ndan sonra da bölgedeki askeri gücü ve Akdeniz'deki deniz üstünlügüyle bu başat konumunu sürdürmek istemekteydi ${ }^{21}$. Bu açıdan Süveyş Kanalı'nın kontrolü İngiltere için hayati önem taşımaktaydı. 1882'de işgal ettiği Mısır'da 1914'de himaye rejimi tesis eden İngiltere, 1919'dan itibaren Vefd Partisi öncülüğündeki milliyetçilerin bağımsızlık talepleriyle karşılaşmış ve 1922'de tek yanlı olarak Mısır’n bağımsızlığını ilan etmiştiti ${ }^{22}$. 1935’te Habeşistan'ı işgal eden İtalya’nın, Kızıldeniz’in çıkışına hakim olması ve Misır ile komşu durumuna gelmesi İngiltere’nin İmparatorluk Yolu için tehdit yaratmış ve endişesine yol açmışt ${ }^{23}$. Bu durum İngiltere'yi, Mısır'daki askeri mevcudiyetini sağlama alacak, aynı zamanda Mısırlı milliyetçileri memnun edecek bir anlaşma imzalamaya sevk etmiş, 1936'da imzalanan anlaşmayla Mısır’n bağımsızlığı tanınmıştır. Ancak anlaşmayla İngiliz askeri mevcudiyetine son verilememiş olması milliyetçileri tatmin etmemiştir. Anlaşmada, İngiltere’nin Süveyş Kanalı bölgesindeki askeri mevcudiyetini koruması ve

17- A.g.m., s.269.

18- A.g.m., s.267.

19- Mehmet Gönlübol ve Haluk Ülman, “Türk Dış Politikasının Yirmi Yllı 1945-1965”, Ankara Üniversitesi SBF Dergisi, C.21, S.1, 1966, s.151.

20- Fahir Armaoğlu, 20.Yüzyıl Siyasi Tarihi (1914-1990) Cilt I: 1914-1980, Türkiye İş Bankası Yayınları, Ankara, 1991, s.441.

21 - Sander, a.g.e., s.22

22- William L. Cleveland, Modern Ortadoğu Tarihi, Çev. Mehmet Harmancı, Agora Kitaplığı, İstanbul, 2015, s. 220 .

23- Armaoğlu, a.g.e., s.443. 
taraflardan birinin savaşa girmesi durumunda diğer tarafın savaşa giren tarafa yardımı etmesi öngörülmekteydi. İki ülke arasında ittifak bağı tesis eden bu anlaşmaya dayanarak İngiltere, İkinci Dünya Savaşı'nda 200 bin civarında askerini Akdeniz savunmasının merkezi yaptığı Mısır'da konuşlandırmış, adeta bir işgal görünümü yaratan bu durum halkın tepkisine ve İngiliz askerlerinin ülkeden çekilmesi taleplerine yol açmıştır ${ }^{24}$. Gizli Mısır Komünist Partisi, Şeyh Hasan en-Banna liderliğindeki Müslüman Kardeşler Örgütü (MKÖ) ve Vefd Partisi İngiltere karşıtlı̆̆ını körüklemektedir.

Savaşın bitmesiyle birlikte Mısır, 1936 anlaşmasının feshedilmesi ve İngiliz kuvvetlerinin çekilmesi taleplerini gündeme getirirken, İngiltere Süveyş'in Ortadoğu'daki çıkarları açısından taşıdığı stratejik önem ve Sovyet faktörü nedeniyle, bu taleplere karşı Süveyş’te varlığının devamını sağlayacak yollar aramaya başlamıştır. İngiliz kontrolü altında bir Ortadoğu savunma düzeni oluşturma düşüncesi bu arayış sonunda ortaya çıkmıştır. İngiltere ile birlikte Türkiye, Yunanistan ve Mısır’n katılacağı bu düzen içinde Süveyş’teki İngiliz birlikleri üslerinde kalarak, başında bir İngiliz komutanın bulunduğu Ortadoğu Komutanlığı’nın emri altında olacaklard ${ }^{25}$. Türkiye'nin NATO'ya girmesini bir süre geciktirecek olan bu İngiliz projesi, 1950'den sonra ABD’nin de desteğiyle farklı şekiller alacaktır.

1936 Anlaşması'nın 20 yıl için imzalanmış olması nedeniyle 1956'da gözden geçirilmesi gerekmekle birlikte İngiltere, bağımsızlık akımlarının hız kazandığı, eski sömürgelerin uluslararası toplumun eşit üyeleri olmaya başladığı ve ABD’nin bu akımları desteklediği İkinci Dünya Savaşı sonrası dönemde şiddet siyaseti izleyemeyeceğinin farkındaydı ${ }^{26}$. Bu nedenle 1945 yılının sonunda anlaşmanın gözden geçirilmesini kabul etmiş ve taraflar arasındaki görüşmeler Ekim 1946'da yeni bir anlaşma tasarısı üzerinde uzlaşıya varılmasıyla sonuçlanmıştır. Ancak İngiltere’nin, Mısır-İngiltere ortak yönetimindeki Sudan'ın da statüsünü de netleştirmek ve Sudan'a bağımsızlık vermek istemesi, bu ülkenin Mısır ile birleşmesini amaçlayan Mısır Yönetimi’nin itirazıyla karşılaşınca anlaşmanın imzalanması mümkün olmamış ve Mısır konuyu Temmuz 1947'de BM Güvenlik Konseyi’ne götürmüştür ${ }^{27}$. Meseleyi 1948'de ele alan Güvenlik Konseyi’nde Misır'ı sadece Sovyetler Birliği ile Polonya desteklemiş ${ }^{28}$, müzakerelerden bir sonuç çıkmamıştır. Sovyetler Birliği'nin İngiltere-Mısır anlaşmazlı̆̆ında Mısır’’ desteklemesi, Ortadoğu'da etkinlik sağlama ve Batı/İngiltere etkisini zayıflatma politikasının bir örneği olmuştur.

Sovyetler Birliği'nin Akdeniz ve Ortadoğu'ya yönelik niyetleri, 1947'de ABD’yi Türkiye ve Yunanistan’a askeri ve ekonomik yardım yapılmasını öngören Truman Doktrini’ni

\footnotetext{
24- A.g.e., s.493.

25- Haluk Ülman, "Türk Dış Politikasına Yön Veren Etkenler I (1923-1968)", Ankara Üniversitesi SBF Dergisi, C.23, S.23, 1968, s.271.

26- Kamuran Gürün, Dış İlişkiler ve Türk Politikası (1939’dan Günümüze Kadar), Ankara Üniversitesi Siyasal Bilgiler Fakültesi Yayınları, Ankara, 1983, s.310.

27- Armaoğlu, a.g.e., s.494.

28- Gökhan Erdem, "Bağlantısızlıktan Bağımlılığa: Nasır Döneminde Mısır-SSCB İlişkileri”, Turkish Yearbook of International Relations, C.48, 2017, s.73.
} 
ilan etmeye yöneltmiştir. Bölgedeki stratejik çıkarlarını ancak ABD’nin desteğiyle koruyabileceğini düşünen İngiltere'nin, Türkiye ve Yunanistan ile ilgili olarak ABD’ye verdiği muhtıraların Truman Doktrini'nin ortaya çıkmasında önemli payı vardır ${ }^{29}$. ABD'yi Truman Doktrini'yle Türkiye ve Yunanistan'a yardımda bulunmaya iten neden Sovyet davranışlarının ortaya çıkardığı yeni uluslararası ortamdır ${ }^{30}$. Doktrin'in ana amacı Sovyet genişlemesini durdurmak ve Amerikan ekonomik ve siyasal anlayışının gelişmesini sağlamaktır ${ }^{31}$. Bu genel tablo içinde Türkiye’nin, Sovyetler Birliği’nin Akdeniz’e ve Ortadoğu’ya doğru genişlemesini engellemekte ve gerektiğinde Sovyetler Birliği’ne karşı girişilebilecek bir harekette stratejik konumuyla sahip olduğu değer, Türkiye’ye yönelik yardımın spesifik nedenlerini oluşturmaktadır. Türkiye bakımından ise Truman Doktrini Sovyet tehdidine kaşı ABD desteği elde ederek içinde bulunduğu yalnızlıktan kurtulmak, savaş sonrasında ihtiyaç duyduğu ekonomik ve askeri yardımı temin etmek anlamına gelmektedir. ABD Türkiye’nin savaş sonrasında ihtiyaç duyduğu ekonomik desteği sağlayabilecek tek ülkeydi, ayrıca kolonyal geçmişinin olmaması ve Türkiye'ye coğrafi olarak oldukça uzak olması da Türkiye için önemliydi ${ }^{32}$. Truman Doktrini, Türkiye’nin güvenlik endişelerini azaltmış, ancak tam olarak gidermemiştir. Doktrin çerçevesinde Temmuz 1947'de imzalanan yardım anlaşmasının tek taraflı olması nedeniyle Türkiye, ABD ile bir ittifak ilişkisi arayışı içinde olmuş ${ }^{33}$ ve 1949 'da kuruluşundan itibaren NATO'ya üye olma girişimlerini sürdürmüştür.

İkinci Dünya Savaşı'ndan sonra Ortadoğu'da meydana gelen ve bölgedeki etkisini günümüze kadar sürdüren en önemli gelişme şüphesiz ki Filistin'in taksimi olmuştur. Türkiye, 1947'de İngiltere tarafından BM gündemine getirilen bu meselede Arap ülkeleriyle birlikte davranarak Filistin’in taksimine karşı çıkmış ve bağımsız Arap/Filistin devletini desteklemiştir. Türkiye, kurulacak Arap/Filistin devletinin Irak-Ürdün-Türkiye yakınlaşmasına eklenecek, Ürdün’ün liderliğinde Batı yanlısı bir devlet olacağı öngörüsüyle hareket etmiş, bu dönemde Filistin’e göç eden Yahudilerin sosyalist/komünist fikirlerin etkisinde olduğu, bölgede İşçi Siyonizminin egemen olduğu düşüncesi, kurulacak Yahudi devletinin Sovyet nüfuzunda olacağı endişesi uyandırmıştır ${ }^{34}$. Esasen aynı sırada Sovyetler Birliği'nin de kendisi için Ortadoğu'da bir köprübaşı olabilecek, milliyetçi ve İngiliz karşıtı bir Yahudi devletinin kurulabileceği görüşünde olduğu anlaşılmaktadır ${ }^{35}$. Sovyetler Birliği’nin esas itibariyle İngiltere'nin bir an önce bölgeden çekilmesini sağlamak amacıyla taksim kararını desteklediği açıktır. Sovyetler Birliği’nin, anti-emperyalist politikasının bir gereği olarak ortaya konsa da, Filistin'in taksimini destekleme kararı, Arapların tepkisini çekmiştir.

29- Armaoğlu, a.g.e., s.441-442.

30- Gönlübol ve Ülman, a.g.m., s.153.

31- Sander, a.g.e., s.40.

32- Mustafa Aydın, "Determinants of Turkish Foreign Policy: Changing Patterns and Conjunctures during the Cold War", Middle Eastern Studies, C.36, S.1, 2000, s.109.

33- Sander, a.g.e., s.65.

34- Özlem Tür, “Türkiye ve Filistin (1908-1948): Milliyetçilik, Ulusal Çıkar ve Batılılaşma”, Ankara Üniversitesi SBF Dergisi, C.62, S.1, 2007, s.248.

35- J. Fred Khouri, The Arab-Israeli Dilemma, Syracuse University Press, New York, 1985, s.50. 


\section{1947-1954 DÖNEMİ}

1947-1954 dönemi; İsrail devletinin kurulduğu, 1948 Arap-İsrail Savaşı’nda Arapların ağır bir yenilgiye uğradığı, bu yenilgiden sorumlu tutulan yöneticilere karşı büyük tepkilerin doğduğu ve Arap milliyetçiliğinin hız kazandığı bir dönemi işaret etmektedir. Manda yönetimlerinin sona ermesiyle artık tümü bağımsızlıklarını kazanan Arap ülkeleri için İsrail yeni bir tehdit olarak ortaya çıkmıştır. Yahudiler bağımsız devletlerini kurarken, Filistinliler bağımsız devlet hayallerini de, topraklarını da kaybetmiş durumdadır. 1948 Savaşı'nın sonunda İsrail, taksim planında kendisine ayrılan topraklardan daha fazlasını elde ederken, Mısır Gazze’yi, Ürdün Batı Şeria ve Doğu Kudüs'ü işgal etmiştir.

1948'deki Arap-İsrail Savaşı, dışarıdan bir saldırı olması halinde Arapların bölgeyi savunamayacaklarını ortaya çıkarmış ${ }^{36}$, İngiltere’nin Ortadoğu savunma sistemi kurma düşüncesini ve Süveyş̧te kalma kararını pekiştirmiş, İsrail devletinin kurulması da ABD’nin Ortadoğu güvenliğine daha fazla önem vermesi sonucunu doğurmuştur. ABD’nin Ortadoğu’ya yönelmesi, Süveyş ve Ortadoğu'daki varlığını sürdürmek isteyen İngiltere için bir firsat sunmaktayd ${ }^{37}$. Böylece, Haziran 1951'den itibaren ABD'nin de desteğiyle Ortadoğu Komutanlığı adıyla Süveyş’te bir müttefik karargahı kurma fikri ortaya çıkacak, Batı yanlısı Müslüman bir Ortadoğu ülkesi olarak Türkiye’nin de işin içine katılması, Türkiye-Mısır ilişkilerini uzun süre olumsuz etkileyecek bir sürecin başlangıcını oluşturacaktır. Türkiye, başından itibaren Ortadoğu Savunma Düzeni ya da Ortadoğu Komutanlığ 1 gibi isimlerle gündeme getirilen bir bölgesel savunma oluşumunun içinde yer almaya istekli olmamış ve bu yüzden NATO’ya girmesini engelleyen İngiltere ile ilişkilerinde de zaman zaman soğukluk yaşanmıştır. Türkiye, Nisan 1950'de, kendisinden Mısır nezdinde girişimde bulunmasını isteyen İngiltere'ye, Türkiye ile İngiltere’nin Arap devletlerine karşı birlikte politika geliştirebilmesi için öncelikle Filistin sorununun çözülmesi gerektiğini, bu takdirde Mısır’ın söz konusu organizasyona katılabileceğini bildirmişti ${ }^{38}$.

1949'da Sovyetler Birliği’nin atom silahına sahip olması, 1950 Çin- Sovyet ittifakı ve aynı yıl başlayan Kore Savaşı nedeniyle ${ }^{39}$ Türkiye'nin Ortadoğu'da artan önemini ve Kore Savaşı'ndaki katkılarını dikkate alarak NATO'ya girmesini gerekli gören ABD’nin etkisiyle İngiltere, 1951'de Türkiye'ye, Müttefik Komutanlığı'na katılması karşılığında NATO üyeliğini destekleyeceğini belirten bir paket anlaşma önermiş ve Türkiye'nin söz konusu oluşumda yer alması şartıyla NATO’ya girmesi kabul edilmiştir ${ }^{40}$.

$\mathrm{Bu}$ çerçevede; Türkiye, ABD, İngiltere ve Fransa 13 Ekim 1951'de ortak bir notayla Ortadoğu Komutanlığı tasarısını Mısır’a sunmuş ve beklenebileceği gibi Mısır, emperyalist

36- Gürün, a.g.e., s.304.

37- Fahir Armaoğlu, Türk Amerikan İlişkileri 1919-1997, Kronik Kitap, İstanbul, 2017, s.125.

38- Mustafa Edip Çelik, "İkinci Dünya Savaşı Bitiminden Bağdat Paktı’na Geçen Süreçte Türkiye’nin Ortadoğu Politikası”, Türkiyat Araştırmaları Enstitüsü Dergisi, TAED-64, Ocak 2019, s.482.

39- Sander, a.g.e., s.88-93.

40- Armaoğlu, Türk Amerikan..., s.126. 
niteliğini vurgulayarak teklifi reddetmiştir ${ }^{41}$. Mısır çeşitli formüller altında önüne getirilen ve Süveyş̧te yabancı egemenliğinin devamını öngören bu teklifler karşısında 15 Ekim 1951'de, 1936 anlaşmasını yürürlükten kaldırma kararı almıştır. Bu karar, ülkedeki İngiliz aleyhtarlığını körüklemiş, İkinci Dünya Savaşı sonrasında başlayıp 1948 Arap-İsrail Savaşı'ndaki ağır Arap yenilgisinden de etkilenerek devam eden kargaşalıkları daha da arttırmıştır. Komünistlerin, MKÖ’nün ve milliyetçilerin teşvikiyle sivillerden meydana gelen Milli Kurtuluş Ordusu ile İngiliz kuvvetleri arasında çarpışmalar yaşanmış, İngiliz mağazaları yağma edilmiştir ${ }^{42}$. İngilizlerin İsmailiye'de bir polis kışlasına saldırarak 50 Misırlı polisi öldürmesi üzerine Ocak 1952'de başlayan gösteri ve ayaklanmalar, asayişin tamamen ortadan kalkmasına ve 23 Temmuz 1952'de Albay Cemal Abdülnasır liderliğindeki Hür Subaylar Komitesi’nin darbeyle yönetimi ele geçirmesine neden olacaktır ${ }^{43}$. Kral Faruk'u tahtından feragate ve ülkeden çıkmaya zorlayan darbeciler, 1953'te monarşiyi kaldırıp cumhuriyet ilan edecek ve Mısır'da yeni bir dönemi başlatacaklardır.

Mayıs 1950'de İngiltere, ABD ve Fransa’nın yayınladıkları deklarasyonla yeni bir Arap-İsrail çatışmasının ortaya çıkmasını önlemek amacıyla Arap ülkeleri ve İsrail’e silah ambargosu uygulama kararı alması, Arap ülkeleri tarafından kendilerine yönelik bir tedbir olarak görülmüş, İsrail'i ortadan kaldırma imkanlarının ellerinden alınmak istendiği şeklinde yorumlanmıştı. Arap ülkelerinin bu düşünceleri ve İsrail'i tanımamakta devam etmeleri, Batılılar tarafından önerilen Ortadoğu Savunma Paktı fikrini sürekli reddedişlerinin ana sebebi olmuştur ${ }^{44}$. Arap ülkeleri, bu deklarasyona tepki olarak Haziran 1950'de Arap Kolektif Paktı Anlaşması'nı imzalamışlardı.

1947'de Filistin'in taksimi kararını destekleyen Sovyetler Birliği, 1948 Arap-İsrail Savaşı'nın başlamasından sonra İsrail devletini tanıyarak ve savaşta İsrail’e Çekoslovakya üzerinden silah sağlayarak Arapların tepkisini daha da arttırmıştı ${ }^{45}$. Ancak Sovyetler Birliği, İsrail'in Batı yanlısı politikası netleştikten sonra tutumunu değiştirecek ve 1950'li yıllardan itibaren Arap davasının savunucusu olacak, Arap ülkelerinin ekonomik ve askeri desteğine güvenebilecekleri bir ülke olarak önem kazanacaktır. Bu durum, Türkiye ile Arap ülkeleri arasındaki ilişkileri de etkileyecektir. İlişkileri etkileyen diğer bir faktör de Türkiye’nin İsrail’e yönelik politikasındaki değişiklik olacaktır.

Truman Doktrini çerçevesinde ABD'den yardım almaya başlayıncaya kadar Filistin meselesinde Arapları destekleyen Türkiye, yardım almaya başladıktan sonra önce tarafsızlığa kaymış, daha sonra Mart 1949'da İsrail devletini tanımıştır ${ }^{46}$. İsrail'in Batı/ $\mathrm{ABD}$ ile ilişkileri ve Batıya yakın bir politika izlemesi de bu tutumda etkili olmuştur. Türkiye, İsrail ile ilişkilerinin Batı ile ilişkilerinin gelişmesinde de olumlu etkisi olacağını

41- A.g.e., s.126-127.

42- Armaoğlu, 20.Yüzyıl..., s.495-496.

43- Cleveland, a.g.e., s.338.

44- Gürün, a.g.e., s.304.

45- Fahir Armaoğlu, Filistin Meselesi ve Arap-İsrail Savaşları (1948-1988), Türkiye İş Bankası Yayınları, Ankara, b.t.y., s.94.

46- Gönlübol ve Ülman, a.g.m., s.160. 
düşünmüştür ${ }^{47}$.

Türkiye’nin Sovyet tehdidi karşısında İkinci Dünya Savaşı’nın sonundan itibaren sürdürdüğü Batı ile ittifak arayışları, Şubat 1952'de NATO’ya girmesiyle son bulmuş, NATO’ya girme karşılığında Ortadoğu Komutanlığı’na katılması ise bölgesel savunma paktlarını Batı’nın emperyalist politikalarının uzantısı olarak gören, yenilgiye uğradıkları 1948 savaşı sonrası İsrail’e karşı kendilerini Batı tarafından yalnız bırakılmış hisseden Arap ülkelerince hoş karşılanmamıştır. Mısır’ın Süveyş’ten çekilmesi konusunda İngiltere ile yaşadığı anlaşmazlıkta Türkiye'nin bir yerde taraf olarak ortaya çıkması ve bu ülkenin egemenlik sorunu olarak gördüğü bir meselede karşı safta yer alması, Misır ve Mısır’ı destekleyen Arap ülkelerince emperyalist güçlerin işbirlikçisi olarak görülmesine yol açmıştır. Bu dönemde, Misır ile ilişkilerde 1930’lu yıllarda İtalya tehdidinin yarattığı yumuşamanın ortadan kalktığı ve tehdit algılamalarındaki farklılıklara paralel olarak dış politik yönelimlerde ortaya çıkan tercihlerin, ilişkileri olumsuz etkilemeye başladığı gözlenmektedir. Bu olumsuzluk, 1954-1960 döneminde daha da artacaktır.

\section{1954-1960 DÖNEMI}

1954-1960 dönemi; Ortadoğu’nun Sovyetler Birliği ile ABD arasında yeni bir çatışma alanı haline geldiği, Sovyetler Birliği’nin bölgede etkisini arttırdığı, Arap "Soğuk Savaşı'nın” şiddetlendiği, bir dizi krizin art arda yaşandığı, sürekli bir çatışma ve istikrarsılılk halinin egemen olduğu bir dönem olmuştur. Türkiye-Mısır ilişkilerinin son derece olumsuz seyrettiği bu dönem üç alt başlıkta incelenecektir

\subsection{Bağdat Paktı'nın Kurulması}

Ekim 1951'de Mısır tarafından reddedilmesine rağmen, Ortadoğu Komutanlığı kuruluş çalışmalarına devam edilmiş, ancak 1953 sonuna kadar bu oluşumla ilgili somut bir gelişme yaşanmamıştır. Oluşuma tüm Arap ülkelerinin katılmasını isteyen ABD, öncelikle Mısır ile İngiltere arasındaki müzakerelerin tamamlanmasını beklemiştir ${ }^{48}$. $\mathrm{Bu}$ arada Türkiye, Başbakan Adnan Menderes'in Ekim 1952'deki İngiltere ziyaretinden sonra daha aktif olarak devreye girmeye başlamış, Ortadoğu Komutanlığı’nın önce Arap ülkeleri olmadan kurulmasını, kuruluşundan sonra bu ülkelerin adım adım Ortadoğu Komutanlığı'na katılabileceklerini savunmuştur ${ }^{49}$. Türkiye bu çerçevede Irak’in yanı sıra, Mısır nezdinde de girişimde bulunmuş, ancak Kanal bölgesi boşaltılmadıkça Mısır’ın bu oluşuma girmeyeceği anlaşılmış, Mayıs 1953’e gelindiğinde Mısır’ın konuya ilişkin kesin tutumunun, Süveyş meselesi çözülse bile bölgesel savunma konusunda Batı ile işbirliğine girmemek yönünde olduğu netleşmiştir ${ }^{50}$. ABD Dışişleri Bakanı Foster Dulles’nn Mayıs

47- Tür, a.g.m., s.248.

48- Armaoğlu, Türk Amerikan..., s.131-132.

49- A.g.e., s.138.

50-A.g.e., s.139-140. 
1953'te bölge ülkelerine yaptığ 1 ziyaretler sonunda Mısır'ı esas alan bir bölgesel oluşumun gerçekçi olmadığı ve güçlü bir savunmanın Pakistan, Irak, Suriye ve Türkiye’nin dahil olduğu Kuzey Seddi’ne dayandırılması gerektiği düşüncesi öne çıkmıştır ${ }^{51}$. Dulles'in Türkiye ziyaretinde Başbakan Menderes'in ifadeleri, Mısır'a bakış açısını göstermesi açısından dikkat çekicidir. Menderes; Süveyşsorununda İngiltere’nin hür dünyanın ileri karakolunu korumak amacıyla hareket ettiğini, Süveyş’in güvenli ellerde olması gerektiğini, Mısır’n sorunu bir bağımsızlık ve özgürlük sorunu şeklinde sunmasının stratejik bakımdan Kanal bölgesinin hür dünya için arz ettiği önemden sonra ancak ikinci derecede öneme sahip olduğunu ve Kanal'ın savunulması için gerekli düzenlemeler yapılıncaya kadar Kanal'ın boşaltılmaması gerektiğini ifade etmiştir ${ }^{52}$. Menderes, Ortadoğu'nun savunulmasında Arap ülkelerinin bir kenara bırakılması ve Türkiye’nin "belkemiğı" olması gerektiğini belirterek $^{53}$, bu konuda Türkiye'nin lider rol oynama arzusunu da ortaya koymuştur.

Pakistan'ın Ortadoğu savunmasına katılma konusunda aktif bir tutum izlemeye başlaması üzerine Nisan 1954'de Türkiye ile Pakistan arasında imzalanan, ancak ittifak niteliği taşımayan Dostane İşbirliği Anlaşması’nın ardından Türkiye ile Irak arasında Ocak 1955’te bir Türk-Irak Anlaşması'nın imzalanması, bu arada Irak'ın Pakistan, Türkiye'nin de Suriye nezdinde girişimde bulunması kararlaştırılmış, bu iki devleti Mısır’ın da izleyebileceği düşünülmüştür ${ }^{54}$. Misır ile İngiltere arasındaki Süveyş anlaşmazlığının Ekim 1954'de imzalanan bir anlaşmayla sonlandırılması ve anlaşmada Arap Ligi üyelerinden birine veya Türkiye’ye bir silahlı saldırı halinde Mısır’ın İngiltere’ye her türlü kolaylığı göstereceğinin, İngiltere’nin boşalttığı üslerin yeniden faaliyete geçirebileceğinin kabul edilmesi ${ }^{55}$, Misır’ın bu kez bölgesel savunma oluşumuna katılabileceği konusunda iyimser bir beklenti yaratmıştır. Bu çerçevede Başbakan Menderes Mısır, Suriye ve Lübnan’ı ziyaret etmeyi planlamış, ancak Nasır'ın reddetmesi nedeniyle Mısır ziyareti gerçekleşemezken, Suriye ziyareti de başarısızlıkla neticelenmiştir. Mısır’’n tutumu karşısında Türkiye ile Irak 24 Şubat 1955’te, Bağdat Paktı adını alan savunma işbirliği antlaşmasını imzalamıştır.

Nasır, Bağdat Paktı'nın Sovyet tehdidini esas aldığı için Araplar bakımından stratejik anlamı olmadığını, Arapların İsrail'e karşı kolektif bir karşı denge oluşturmaları gerektiğini, Bağdat Paktı’nın böyle bir ihtiyaca cevap veremeyeceğini düşünmekteydi ${ }^{56}$. Nasır’a göre Pakt, Batı emperyalizminin bölgedeki mevcudiyetini uzatmak için kurulmuştu. Nasır, Paktın Arap birliğini bozacağını ve bunun da İsrail'in işine yarayacağını öngörmekteydi. Kendi liderliğinde bir Arap dünyası hedefleyen Nasır, Türkiye’nin diğer Arap ülkelerini yanına çekmeye çalışmasından rahatsızlık duymuştur ${ }^{57}$. Irak'ın Pakt'ta yer alması da Nasır'ın Arap dünyasının liderliği pozisyonunu tehdit eden bir gelişme olarak görülmüştür. Irak ise Nasır’ın bölgesel liderlik iddiaları karşısında Türkiye ve Batılı ülkelere yaklaşarak gücünü

51- A.ge., s.156.

52-A.g.e., s.153.

53- A.g.e., s.154.

54- A.g.e., s.167.

55- Gürün, a.g.e., s.313.

56- Avi Shalaim, Lion of Jordan. The Life of King Hussein in War and Peace, Penguin Books, London, 2007.

57- Armaoğlu, Türk Amerikan..., s.169. 
arttırmayı amaçlamaktayd1 ${ }^{58}$. Antlaşmayı Irak adına imzalayan Başbakan Nuri Sait Paşa, Nasır’n bütün bölgede geniş destek gören Arap milliyetçiliği politikasına açıktan cephe almakla büyük bir riske girmekteydi ve bu hatasını 1958 'de hayatıyla ödeyecekti ${ }^{59}$.

Bağdat Paktı́na tüm Arap devletlerinin katılmalarının sağlanması, Paktı bölgesel bir savunma organizasyonuna dönüştürerek Sovyetler Birliği’nin güneye inmesine engel oluşturacaktı ${ }^{60}$. Bu çerçevede, diğer Arap ülkelerinin katılmasını sağlamak amacıyla, antlaşmaya sadece Arap Ligi üyesi olan veya taraflarca tanınan devletlerin katılabileceği kararlaştırılmış, böylece İsrail'in antlaşmaya katılma ihtimali önlenmiştir. Esasen İsrail, Arap ülkelerini bir araya getirecek bir savunma düzeni tesisinin ancak İsrail'in güvenliği pahasına gerçekleştirilebileceği düşüncesiyle Bağdat Paktı’na olumlu yaklaşmamış ${ }^{61}$, Bağdat Paktı’nın kendisine karşı kurulduğunu iddia etmiştir.

Pakt’a Nisan 1955’te İngiltere, Eylül 1955’te Pakistan, Kasım 1955'te İran katılacaktır. Pakt’a Irak dışında Ürdün ve Lübnan gibi Batı yanlısı Arap ülkelerinin de katılabileceği beklentisi ise Mısır'ın tutumu nedeniyle gerçekleşmemiştir. Bölge ülkeleri arasındaki tarihi düşmanlık ve bölünmeler de Pakt’a katılımlarını etkileyen bir faktör durumundadır. Suudi Arabistan, geleneksel rakipleri Irak ve Ürdün'ün yer alacağı Batı savunma planlarına özellikle karşıydı ve Bağdat Paktı’nı Krallı̆̆ının mevcudiyetine yönelik bir tehdit olarak görmekteydi $^{62}$. Bu nedenle Pakt’ta yer almadığı gibi, Misır ile birlikte Ürdün'ün Pakt'a katılmasını engellemeye de çalışmıştı. Suriye, Sovyetler Birliği ile yakın ilişkileri nedeniyle zaten Pakta olumlu bakmamaktaydı. Ayrıca Hatay meselesi nedeniyle Türkiye’nin içinde olduğu bir savunma paktına katılması düşünülemezdi. Ürdün ve Lübnan yönetimleri ise Batı yanlısı olsalar dahi kamuoylarının ve özellikle Nasır’ın tepkisini dikkate almak durumundaydılar. Sonuç olarak Mısır, Bağdat Paktı'na cevaben Ekim 1955’te önce Suriye daha sonra Suudi Arabistan ile savunma işbirliği antlaşmaları imzalamış, Nisan 1956'da da Mısır-Suudi Arabistan-Yemen arasında bir savunma antlaşması gerçekleştirilmiştir. Böylece Bağdat Paktı’na karşı Mısır-Suriye-Suudi Arabistan-Yemen Bloğu ortaya çıkmış, Ürdün ve Lübnan ise her iki blokta da yer almamışlardır ${ }^{63}$.

Türkiye, Bağdat Paktı'nı Sovyetler Birliğinin bölgeye girmesini ve kendisine güneyden de tehdit olmasını önleyecek bir oluşum olarak görmüştür. Arap devletleri ise Türkiye'yi Pakta katıldığı için Batı emperyalizminin aracı olmakla suçlamışlardır. 1950’li yıllarda Türkiye, Arapların İsrail ve Batılı güçlere yönelik hassasiyetlerini nasıl anlayamamısssa,

58- Umut Uzer ve Ayşe Uzer, "Diverging Perceptions of the Cold War: Baghdad Pact as a Source of Conflict Between Turkey and the Nationalist Arab Countries”, Turkish Yearbook of International Relations, C.36, 2005, s. 117 .

59- İlter Türkmen, “Türkiye Cumhuriyeti’nin Ortadoğu Politikası”, BİLGESAM, Temmuz 2014, s.12, www.bilgesam.org/images/dokumanlar/0-22-20140717111.pdf., (Erişim: 05.08.2019).

60- Mahir Küçükvatan, “Soğuk Savaşın Türk Dış Politikasına Etkileri ve 1957 Türkiye-Suriye Bunalımı”, Çağdaş Türkiye Araştırmaları Dergisi, C.XI, S.23, Güz 2011, s.77.

61- Özcan, a.g.e., s.18.

62- Shalaim, a.g.e.

63- Armaoğlu, Türk Amerikan..., s.171. 
Araplar da Türkiye’nin Sovyet tehdidinden duyduğu endişeyi ve güvenlik ihtiyaçlarını anlayamamışlardır. Bu durum, Türkiye ile Arap ülkeleri arasındaki farklı tehdit algılarından ve jeopolitik gerçekliklerden kaynaklanmaktadır ${ }^{64}$. Arap ülkeleri, Sovyetler Birliği'ne coğrafi uzaklıkları ve Türkiye ile İran’ın Arap ülkeleri ile Sovyetler Birliği arasında tampon bölge oluşturması sayesinde doğrudan Sovyet tehdidiyle karşılaşmamışlardır ${ }^{65}$. Arap ülkeleri kısmen “Türk tamponu” sayesinde Sovyetler Birliği ile yakın bağlar oluşturma imkanına sahip olmuş, Türkiye, Arap ülkelerini doğrudan Sovyet tehdidinden koruyan bir güvenlik ve ilişkilerinde rahatlık sağlamıştır. Aynı mantıktan yola çıkarak, Türkiye’nin de "Arap tamponu" sayesinde İsrail ile bağlantı kurma imkanına sahip olduğu ileri sürülebilir ${ }^{66}$.

Bağdat Paktı’nın bölge savunmasına katkısı olmadığı gibi, Sovyetler Birliği’nin bölgeye girişini kolaylaştırıcı bir rolü de olmuştur. Nasır’ın Eylül 1955’te Çekoslovakya ile silah anlaşması yapmasını etkileyen en önemli nedenlerden biri Bağdat Paktı'dır ${ }^{67}$. Bağdat Paktı'nın imzalanmasından dört gün sonra 28 Şubat 1955'te İsrail'in Mısır yönetimindeki Gazze'ye saldırması, Nasır'ın bu gelişmenin Pakt'ın imzalanmasıyla koordineli olduğunu düşünmesine yol açmıştır ${ }^{68}$. 4 Nisan 1955'te İngiltere’nin Pakta katılması Nasır'ın düşüncesini daha da kuvvetlendirmiştir. İsrail ise Gazze çatışmalarının ardından yaptığı açıklamada, $\mathrm{ABD}$ ve İngiltere'nin desteklediği Bağdat Paktı'ndan sonra Arapların tutumunun sertleştiğini ileri sürmüştür ${ }^{69}$.

Gazze çatışmalarının, Mısır’’n İsrail karşısındaki askeri yetersizliğini göstermesi karşısında Nasır silahlanma arayışına girmiş ve ABD'den silah talep etmiştir. Ancak, Mısır’n Bağdat Paktı’na girmemesi, 1954 tarihli İngiltere-Mısır anlaşmasının yarattığı olumlu havayı ortadan kaldırdığı için, askeri yardım talepleri ABD tarafından reddedilmiştir. ABD'den istenen silahların alınamaması üzerine Mısır, Sovyetler Birliği’ne yönelmeye karar vermiş, gizli olarak sürdürülen temaslar sonunda Eylül 1955’te, Mısır ile Çekoslovakya arasında silah anlaşması yapıldığı açıklanmıştır ${ }^{70}$. Bu anlaşma Batılı ülkeler ile İsrail'de büyük tepkiye yol açarken, Nasır'ın Batı silah tekelini kırmadaki başarısı nedeniyle Arap ülkelerinde memnuniyetle karşılanmıştır.

Esasen, Hür Subaylar darbesinin ABD tarafından yaptırıldığını düşünen Sovyetler Birliği ile Mısır’ın ilişkileri, 1955’e gelinceye kadar olumsuz bir seyir izlemiştir. Misır Komünist Partisi darbeye ve askeri yönetime karşı çıkmış, komünistlerin etkili olduğu işçi sendikalarının isyanı geniş bir tutuklama operasyonuna yol açmış, Sovyetler Birliği Mısırlı komünistleri desteklemiştir ${ }^{71}$. Ancak, Mısır’’n ordusunu güçlendirme ve ekonomik

64- Uzer ve Uzer, a.g.m., s.114.

65- Aydin, a.g.m., s.114.

66- Oral Sander, Türkiye’nin Dış Politikası, İmge Kitabevi Yayınları, Ankara, 1998, s.230.

67- Shalaim, a.g.e.

68- Uzer ve Uzer, a.g.m., s.114.

69- Armaoğlu, Filistin Meselesi ve ..., s.136.

70- A.g.e., s.140-141.

71- Erdem, a.g.m., s.77. 
yardım arayışları, Batı’dan silah temin edememesi, Sovyetler Birliği ile ilişkilerini tedricen düzeltmesine neden olacaktır. Sovyetler Birliği de çevreleme politikasını etkisiz kılmak, Batılıların silah tekelini kırmak ve bölgesel etkinliğini arttırmak amacıyla Mısır ile silah anlaşmasına destek verecektir ${ }^{72}$.

Böylece Mısır, Arap ülkelerinin bölgesel paktlara katılımını ve İsrail ile barış yapmalarını sağlamak için yardımları dış politika aracı olarak kullanmayı amaçlayan Batılı ülkelerce Sovyetler Birliği’ne adeta itilmiştir. Mısır ile yapılan silah anlaşması Sovyetler Birliği’nin bölgedeki nüfuzunu güçlendirecektir. 1940'lı yıllarda Türkiye'yi Batı’ya yaklaştırarak, Ortadoğu'dan uzaklaşmasına dolaylı etkide bulunan Sovyet tehdidi ${ }^{73}$, 1950'li yılların ortalarından itibaren Sovyetler Birliği’nin Mısır’n yanında Ortadoğu'ya girmesiyle, Türkiye’nin Ortadoğu politikasını doğrudan doğruya ve olumsuz şekilde etkileyen bir faktör olacaktır ${ }^{74}$. Türk Hükümeti, Ortadoğu ülkelerinin milliyetçi ve Batı karşıtı mücadelelerini yalnız Sovyet nüfuz ve ideolojisinin bölgede güç kazanmasına bağlayacak, bu ülkelerin endişe ve isteklerini anlamayacaktır ${ }^{75}$.

\subsection{Süveyş Krizi ve Eisenhower Doktrini}

Sovyetler Birliğine bölgedeki etkisini arttırma imkanı veren diğer bir gelişme, Ekim 1956'daki Süveyş Krizi olmuştur. Kriz, ABD’nin Mısır’n Sovyetler Birliği ile daha fazla yakınlaşmasını önlemek amacıyla Asvan Barajı́nın yapımı için Mısır’a önce kredi vermeyi kabul edip, sonra Mısır’ın Çin Halk Cumhuriyeti ile diplomatik ilişki kurduğu gerekçesiyle vazgeçmesi ve Nasır’n, yapımına büyük önem verdiği barajın finansmanı için Temmuz 1956'da Süveyş Kanalı’nı işleten İngiliz-Fransız şirketini millileştirme kararı alması üzerine patlak vermiştir ${ }^{76}$. Karar, İngiltere ile Fransa’nın büyük tepkisine yol açmış, özellikle Kanal hisselerinin \% 44'ünü elinde bulunduran ve Kanal'ı en fazla kullanan devlet durumundaki İngiltere'ye büyük bir darbe olmuştur. 1955'te Kanal'dan geçen yüklerin \% 28.3'ü İngiltere’ye aittir ${ }^{77}$. İngiltere, Fransa ve ABD, Kanal şirketine tazminat ödenmesi ve Kanalın Mısır'ın da dahil olduğu uluslararası yönetim altına verilmesi halinde millileştirme kararının kabul edileceği görüşündeydiler. Bu esasları belirlemek üzere, 1888 İstanbul Antlaşması'nı imzalayan devletler ile Kanalı en fazla kullanan devletlerin davet edildiği ve 16 Ağustos 1956'da Londra'da yapilan toplantıda (Misır ve Yunanistan, Misır'in bağımsızlığını ihlal edeceği gerekçesiyle katılmamıştır) Kanalın kayıtsız şartsız Mısır egemenliğine bırakılması görüşünü savunan Sovyetler Birliği, Hindistan, Endonezya ve Seylan dışındaki devletler, Kanalın yönetim ve denetiminin Mısır’ın egemenlik haklarına halel getirmeyecek şekilde düzenlenmesi, millileştirilen Kanal şirketinin yerine Mısır ile

72- A.g.m., s.80.

73- Aydın, a.g.m., s.114

74- Ömer Kürkçüoğlu, "An Analysis of Turkish-Arab Relations", Ankara Üniversitesi SBF Dergisi, C.27, S.1, 1972, s.120.

75- Haluk Ülman ve Oral Sander, “Türk Dış Politikasına Yön Veren Etkenler: 1923-68 II”, Ankara Üniversitesi SBF Dergisi, C.27, S.1, 1972, s.10.

76- Armaoğlu, 20.Yüzyıl.., s.498-499.

77- Gürün, a.g.e., s.315. 
uluslararası bir organın geçmesi görüşü üzerinde mutabakata varmışlardır ${ }^{78}$. Türkiye'nin, Boğazlar nedeniyle hassasiyet arz edebilecek bu konuda tutumunu belirlerken temkinli bir havada olduğu, Türk basını Mısır'ı eleştirirken resmi çevrelerin sessizliğini koruduğ ${ }^{79}$ belirtilmekte ise de sonuç olarak Mısır’n karşısında yer aldığı görülmektedir.

Mısır’n bu teklifi reddetmesi üzerine 19-22 Eylül 1956 tarihlerinde Londra'da yapılan ikinci toplantıda, ABD Dışişleri Bakanı Dulles’ın Kanala uluslararası statü verilmesine ilk adım olarak bir "Süveyş Kanalını Kullananlar Birliği” kurulması önerisi ele alınmış ve 1 Ekim 1956'da söz konusu birliğin kurulması kararlaştırılmış ${ }^{80}$, bu arada İngiltere ile Fransa konuyu BM Güvenlik Konseyi’ne de götürmüştür. Güvenlik Konseyi 13 Ekim 1956 tarihli kararında Mısır’n Kanal üzerindeki egemenliğini tanımış, Kanalın ulaşım serbestisi esasına uygun olarak işletilmesi amacıyla bazı genel prensipler tespit etmişse de, BM Genel Sekreteri’nin Mısır ile temasları netice vermemiş, bu sırada İngiltere, Fransa ve İsrail Mısır’a askeri harekat başlatılması kararı almıştır ${ }^{81}$. 29 Ekim 1956'da İsrail'in Sina'daki çatışmaları bahane ederek Sina’ya saldırısıyla başlayan operasyon, İngiltere ile Fransa’nın Kanal bölgesini korumak gerekçesiyle bölgeye düzenledikleri harekatla devam etmiş, Mısır ordusu büyük zayiat vererek Sina'dan çekilmiş ve ağır bir yenilgiye uğramıştır. Sovyetler Birliği’nin Macaristan'daki ayaklanmayı bastırmasını müteakip İngiltere ve Fransa'ya gönderdiği ve bu ülkelere saldırı tehdidini içeren mesajları ve ABD’ye, Mısır'a ortak kuvvet göndererek savaşı durdurma teklifinde bulunması, ABD’nin konuyu BM'ye götürüp, İsrail, İngiltere ve Fransa’yı sert şekilde uyararak, kuvvetlerini Mısır'dan çekmelerini istemesi, bu ülkeleri harekatı durdurmaya mecbur etmiştir. Böylece, İngiltere, Fransa ve İsrail'in Mısır'dan çekilmesi -İsrail BM Barış Gücü’nün bölgede konuşlanmasından sonra Sina'daki askerlerini çekecektir- sağlanmış ve kriz sonlandırılmıştır. Harekat, bölgenin eski sömürgeci güçlerinin İsrail birlikte, sadece Mısır’n egemenlik haklarına değil, Mısır rejimini de devirmeye yönelik bir saldırısı olarak görülmüştür. Gerçekte üç ülkenin de Nasır’ı devirmek istediği bilinmekteydi ve Türkiye ile Irak’ın böyle bir gelişmeden memnuniyet duymaları tabiiydi. Irak’ın İngiliz yanlısı başbakanı Nuri Sait Paşa, Süveyş Krizi’ni Nasır’ın liderliğine vurulan bir darbe olarak görmekte, Nasır’n İngiltere’nin tekliflerini kabul etmesi halinde Batı’nın isteklerine boyun eğdiği için, reddetmesi halinde ise askeri harekatla karşılaşacağı için prestijini yitireceğini ve Irak'ın Mısır'ın zayıflamasından doğan boşluğu doldurarak Arapların liderliğine oynayabileceğini düşünmekteydi ${ }^{82}$. Ancak gelişmeler tam tersi bir durumu ortaya çıkarmıştır.

İngiltere’nin Süveyş harekatındaki rolü, Bağdat Paktı’nın Müslüman üyelerini zor durumda bırakmış, Paktın İngiltere’nin davet edilmediği 5-8 Kasım 1956 tarihli Tahran toplantısında İsrail, Mısır'a saldırısı nedeniyle kınanırken, İngiltere ve Fransa'dan da askerlerini

78- Gürün, a.g.e., s.315-316.

79- Sander, Türk-Amerikan..., s.201.

80- Gönlübol vd., a.g.e., s.291-292.

81- Gürün, a.g.e., s.316.

82- Sabit Duman, “Ortadoğu Krizleri ve Türkiye”, Ankara Üniversitesi Türk İnkılap Tarihi Enstitüsü Atatürk Yolu Dergisi, S.35-36, Mayıs-Kasım 2005, s.321. 
Mısır'dan çekmeleri istenmiştir. Yine Kasım 1956'da Bağdat'ta yapılan toplantıda, İsrail'in bölge barışı için büyük bir tehlike olduğu üzerinde anlaşmaya varılmış, Türkiye'nin İsrail ile diplomatik ilişkilerini kesmesi konusu ele alınmış ve Türkiye 26 Kasım 1956'da İsrail ile diplomatik ilişkilerini maslahatgüzarlık seviyesine indirmiştir ${ }^{83}$. Türkiye’nin bu kararında, Irak’ın Arap dünyasında zor durumda kalmasını önleme düşüncesi de rol oynamıştır. Zira Pakt'in tek Arap üyesi olan Irak Arap dünyasına ihanetle suçlanmaktaydı. ABD’nin, 29 Kasım 1956'da yayınladığı basın bildirisiyle Bağdat Paktı devletlerini desteklediğini ve üye devletlere girişilecek bir saldırıyı çok tehlikeli bir hareket olarak göreceğini açıklaması ${ }^{84}$, Pakt üyelerini nispeten rahatlatan bir gelişme olmuştur.

Süveyş Krizi, ağır askeri yenilgisine rağmen, Nasır için siyasi açıdan büyük bir zafer olmuş, emperyalist güçlere boyun eğmemesi Arap dünyasında Nasır'ı bir kahraman haline getirmiş, Nasır'ın şahsında somutlaşan Arap milliyetçiliği bütün bölgede yükselişe geçmiştir. Nasır'ın Arap dünyasındaki gelişmeleri belirleyici rolü, Süveyş Krizi’nden sonra daha da artmış, bölgede art arda meydana gelen siyasi krizlerde görüleceği gibi "ilericimuhafazakar" ya da "radikal-ılımlı" rejimler arasındaki mücadeleyi körüklemiştir. Diğer yandan Süveyş Krizi, Araplar için tehdidin İsrail ve Batı olduğu gerçeğini bir kez daha göstermiştir. Mısır’ı işgal eden Sovyetler Birliği değil, ama bölgenin eski sömürgecileri İngiltere ve Fransa ile Ortadoğu politikasının yeni aktörü İsrail'dir ${ }^{85}$.

Süveyş Krizi, Batı’nın Ortadoğu'daki prestijine büyük bir darbe vururken, Sovyetler Birliği'nin itibarını arttırmış ve ABD'de bölgede meydana gelen boşluğun bu ülke tarafından doldurulabileceği endișesi yaratmıştı. ABD, zamanlamasından haberdar edilmediği harekattan, uzun süreli çıkarları ile uyuşmadığı için rahatsızlık duymuştu. ABD, İngiltere ve Fransa'yı desteklememesi durumunda bölgedeki prestijini yükseltebilir, İngiltere ve Fransa'yı desteklemesi halinde ise Arap ülkeleri nezdindeki imajının daha da bozulması ve bu ülkeleri Sovyetler Birliği’nin kucağına atma riskiyle karşılaşabilirdi. Bu nedenle ABD, Fransa ve İngiltere’ye karşı Sovyetler Birliği ile alışılmamış bir ittifak kurmuştu $^{86}$. Şüphesiz ki ABD için prestijini arttırmaktan çok daha önemli olan husus, Ortadoğu petrolleri ve Süveyş'in stratejik önemiydi. Süveyş Krizi'nden sonra ABD, bölgede meydana gelen boşluğun Sovyetler Birliği tarafından doldurulmasına izin vermemek ve bu boşluğu bizzat doldurmak şeklinde formüle edilebilecek bir yaklaşımla Ocak 1957'de Eisenhower Doktrini'ni ilan etmiştir. Truman Doktrini’nden farklı olarak tüm Ortadoğu’yu kapsayan Eisenhower Doktrini, bölge ülkelerine ekonomik yardım sağlamayı ve komünizme karşı koymalarına yardım etmeyi öngörmekteydi. Uluslararası komünizmin kontrolü altında bulunan herhangi bir devletten gelecek açık bir saldırıya karşı yardım talep eden bölge ülkelerine Amerikan askeri kuvvetlerinin kullanılması da dahil olmak üzere gerekli yardım sağlanacaktı ${ }^{87}$. Kısacası, ABD gerekirse zor kullanarak

83- Sander, Türk-Amerikan..., s.203.

84- A.g.e., s.204.

85- Uzer ve Uzer, a.g.m., s.108.

86- Sander, Türk-Amerikan..., s.202.

87- Armaoğlu, 20. Yüzyıl..., s.202. 
Sovyetler Birliği’nin Ortadoğu’ya nüfuz etmesini önleme kararlılığındaydı. Eisenhower Doktrini bölge ülkelerine ekonomik yardımı da öngörmekte ve daha önce olduğu gibi bir bölgesel pakta katılma şartını ileri sürmemekteydi. Ancak Doktrin’in komünist tehdit vurgusu, ekonomik kalkınma, siyasal bağımsızlık ve Filistin meselesinin başlıca endişeleri teşkil ettiği bölgesel sorunlarla uyumlu değildi ${ }^{88}$.

Doktrin; Sovyetler Birliği, Suriye ve Mısır tarafından şiddetle eleştirilirken Türkiye, İran, Irak, Lübnan ve Libya tarafından desteklenmiş, Suudi Arabistan önce olumsuz tepki vermişse de sonra Doktrini olumlu bulduğunu açıklamıştır. Ürdün de Doktrini reddeden ülkeler arasındadır. Doktrin'e yönelik tepkiler, ABD ve Sovyetler Birliği'ni Ortadoğu'da karşı karşıya getirecek krizler dönemini başlatmıştır.

\subsection{Ortadoğu Krizleri}

\subsection{1. Ürdïn Krizi}

Eisenhower Doktrini’ni kabul etmemekle birlikte Doktrinin uygulandığı ilk ülke Ürdün olmuştur. Ürdün krizi, Nasır yanlıları ve milliyetçiler ile Krallık yanlıları arasındaki iktidar mücadelesinden ve Suriye’nin kışkırtmalarından kaynaklanmıştır. Ürdün'de Ekim 1956 seçimlerini kazanarak Başbakanlığa gelen milliyetçi ve sol görüşlü Süleyman elNabulsi ile Kral Hüseyin arasında Nabulsi’nin Kral yanlılarını emekliye ayırması, 1948 tarihli İngiltere-Ürdün anlaşmasını kaldırarak, Mısır, Suudi Arabistan ve Suriye ile Arap Dayanışması Anlaşması'nı imzalaması gibi konularda başlayan sürtüşmeler ${ }^{89}$ ve ordudaki Nasır yanlısı milliyetçi subayların Nabulsi’ye bağlılık göstermesi, Nabulsi'nin Nasır yanlısı Genelkurmay Başkanı Ali Abu Nuvar ile işbirliği yaparak Kral Hüseyin'i devirmeyi planladığ1 söylentileri, Kral Hüseyin'in Nabulsi'yi azletmesine neden olmuştur ${ }^{90}$. Nabulsi’nin görevden alınması geniş protesto gösterilerine yol açmış, karışıklıklar orduya da sıçramış ve Kral'a bağlı kuvvetlerle solcu askerler arasında silahlı kuvvetler karargahının bulunduğu Zerka'da çatışmalar meydana gelmiştir ${ }^{91}$. Arkasında Abu Nuvar'in bulunduğu ve Süveyş Krizi nedeniyle Zerka’ya gelmiş olan Suriye birliklerinin kışkırtmasının da rol oynadığı ayaklanma Kral’a bağlı askerler tarafından bastırılmış, Abu Nuvar ve Nuvar'dan sonra Genelkurmay Başkanlığı'na getirilen General Hayari Suriye’ye kaçmıştır ${ }^{92}$. Suriye'nin bu liderlerin Ürdün'e dönmesini sağlamak için Ürdün’e müdahale etme olasılı̆ $1_{1}^{93}$ ve Kahire ve Şam radyolarının Kral Hüseyin aleyhine yayınlarının da etkisiyle Ürdün'de durumun karışması, grev ve gösterilerin sürmesi üzerine, Kral Hüseyin olayların uluslararası komünizm ve taraftarlarınca yaratıldığına ilişkin bir açıklama

88- Uzer ve Uzer, a.g.m., s.115.

89- Mohamed Abu Rumman, Ürdün'de 1989-2005 Arası Demokratik Dönüşüm”, Yayınlanmamış Doktora Tezi, Ankara Üniversitesi Sosyal Bilimler Enstitüsü Kamu Yönetimi ve Siyaset Bilimi Ana Bilim Dall, Ankara, 2009, s.109.

90- Armaoğlu, 20.Yüzyıl..., s.505.

91- Abu Rumman, a.g.e., s.109.

92- Armaoğlu, 20.Yüzyıl..., s.505.

93- Gönlübol vd., a.g.e., s.301. 
yapmış, bu açıklama, Kral'ın Eisenhower Doktrini'nin uygulanmasını istediği şeklinde yorumlanmıştır. ABD’nin Ürdün'ün bağımsızlık ve toprak bütünlüğüne hayati önem verdiğini açılkaması, Altıncı Filo’nun Lübnan önlerine gelmesi, Irak ve Suudi Arabistan'ın Ürdün'ün yanında yer alması, Kral Hüseyin'in olayları önlemesini ve krizin sona ermesini sağlamıştır ${ }^{94}$. Ürdün krizi sırasında basında; Suriye’nin Ürdün’e harekata girişmesi halinde Türkiye’nin de Suriye’ye doğru harekete geçebileceği, Türkiye'nin güney sınırlarında manevralarını sürdürdügü, Türkiye’nin Suriye’nin Ürdün'e doğru hareketini engelleyerek Ortadoğu barışına katkıda bulunmuş olacağ şseklinde haberlerin yer alması ${ }^{95}$, krizin daha da boyutlanması halinde Türkiye’nin nasıl bir rol oynayabileceğini göstermekteydi.

\subsubsection{Türkiye-Suriye Krizi}

Ürdün krizinin ABD ile Sovyetler Birliği arasında ciddi bir sürtüşmeye yol açmadan sona ermesine karşın, Ağustos 1957'de meydana gelen Suriye krizi, ABD ile Sovyetler Birliği'ni karşı karşıya getirecek ve uluslararası bir boyut kazanacaktır. ABD; Ürdün, Lübnan, Irak, İsrail ve Türkiye gibi Batı yanlısı ülkelerle sınırdaş olan Suriye’ye, bu merkezi konumu, Sovyetler Birliği'nin ülkede etkinlik sağlamasına zemin hazırlayan hassas siyasi yapısı, Sovyetler Birliği’nden silah alımları ve Mısır ile ilişkileri nedeniyle özel önem vermekteydi. Irak petrollerini Akdeniz'e ulaştıran petrol boru hattının Suriye'den geçmesi de Batı́nın stratejik çıkarları bakımından önemli görülüyordu. Dolayısıyla Suriye’nin Sovyet etkisinden kurtarılması bölgedeki dengeleri tamamıla değiştirebilirdi. Suriye’de 1954 darbesiyle Albay Edip Çiçekli yönetiminin son bulması sivil siyasetin önünü açmış, 1954 seçimlerinde elde ettiği sonuçla Suriye siyasetinde söz sahibi olan Baas Partisi'nin ülkedeki sol gruplar ve özellikle Sovyet etkisindeki Suriye Komünist Partisi ile işbirliği ve Sovyetler Birliği ile yakın temasları ABD’yi endişelendirmişti"i ${ }^{96}$ Bu dönemde ABD’nin çeşitli kurumları tarafindan Suriye ile ilgili olarak hazırlanan raporlarda, Baas Partisi ile Komünist Partisi'nin çok iyi organize oldukları, orduda ve bürokraside önemli mevkileri ele geçirdikleri, buna karşılık muhafazakar grupların bölünmüş durumda olduğu, parlamentoda sol karşıtı vekiller çoğunlukta olduğu halde parçalanmışlık nedeniyle sola karşı güçlü muhalefet yapamadıkları, Batı karşıtlığını kullanarak Arap ülkelerinde yoğun bir diplomatik faaliyet yürüten Sovyetler Birliği’nin, siyasi zeminin oldukça kırılgan olduğu Suriye’de uygun bir alan bulduğu, Suriye’nin Sovyetler Birliği ve Doğu Bloğu ile başta askeri olmak üzere bütün alanlarda ilişkilerinin geliştiği, "kendisini komünist olarak görmeyen” hükümetin Batı karşıtı propagandanın baskısı altında bulunduğu, Süveyş Krizinden sonra Sovyet nüfuzu ve komünist söylemlerin arttığı, aralarında birlik oluşturamayan sağcı partilerin Batı karşıtlı̆̆ından beslenen sol söylemler karşısında etkisiz kaldığı, Suriye’de Batı karşıtlığının yaygınlığı oranında bir komünizm taraftarlığından söz etmenin ise mümkün olmadığ şeklinde değerlendirmeler yapılmaktadır $^{97}$. Bu tespit ve değerlendirmelerin ABD’yi Suriye'de komünizm karşıtı bir

94- Armaoğlu, 20.Yüzyll.., s.505.

95- Sander, Türk-Amerikan..., s.216.

96- Ali Çakırbaş, "Amerikan Perspektifinden 1957 Krizine Giden Süreçte Suriye'de Komünizmin Yükselişi”, History Studies, C.10, S.6, Eylül 2018, s.38.

97- A.g.m., s.39-41. 
darbe için uygun koşulların olduğu sonucuna götürdüğü anlaşılmaktadır. ABD’ye göre Suriye'de komünizm taraftarlığı güçlü değildir, çoğunluktaki sağ partiler ise bölünmüşlük nedeniyle sola karşı etkili olamamaktadır. O halde komünizm karşıtlarını/sağ partileri organize etmek gerekmektedir. Amerikan Haber Alma görevlilerinin 1957 başından itibaren Suriye'deki sağ çevrelerle, özellikle Baasçlların izledikleri politikadan hoşnut olmayan Genelkurmay Başkanı General Nizamettin ve bazı sağcı partilerin liderleriyle temasa geçtikleri, Suriye hükümetinin 13 Ağustos 1957'de Şam'daki Amerikan Kara Ataşesi ile iki diplomatın görevden alınmasını istediği, hemen ardından 17 Ağustos'ta da yüksek rütbeli subaylar arasında tasfiye yapılarak Genelkurmay Başkanlığına General Nizamettin'in yerine komünist eğilimli Albay Afif el-Bızri’nin getirildiği ${ }^{98}$ şeklindeki bilgiler dikkate alınacak olursa, ABD'nin başarısız bir darbe girişiminde bulunduğu sonucuna varılabilmektedir. ABD muhtemelen "kendisini komünist olarak görmeyen" Suriye hükümetinin Eisenhower Doktrini çerçevesinde ABD'den yardım istemesini sağlamayı hedeflemekteydi. Ancak girişimin ortaya çıkarılması Sovyetler Birliği’nin karşı hamlelerine ve Sovyet karşıtlarının tasfiyesine yol açmış görünmektedir. Bu gelişmelerin yanı sıra, Ağustos 1957 başında, Suriye’nin komünist eğilimli Savunma Bakanı Halid elAzim'in Temmuz 1957'deki Moskova ziyareti sırasında Sovyetler Birliği ile Suriye arasında ekonomik ve askeri anlaşmalar yapıldığının duyulması, büyük bir krizin çıkmasına neden olmuştur. Anlaşma ile Sovyet sivil ve askeri uzmanlarının Suriyede bulunmalarının yolu açılıyor, böylece Sovyetler Birliği bir Ortadoğu ülkesine ayak basma imkanını elde ediyordu ${ }^{99}$. Bu gelişmeler, Türkiye, Irak, Ürdün, Lübnan ve İsrail'de büyük endişe yaratmış, Türkiye kuzeyden ve güneyden Sovyet tehdidi ile karşı karşıya olduğunu değerlendirerek Suriye sınırında askeri tedbirler almaya yönelmiştir. Türkiye'nin ihtiyatları silah altına çağırması ve Suriye sınırında manevralar yapması, ABD’nin gerektiğinde Amerikan askeri gücünün kullanılabileceğini göstermek için Altıncı Filo’yu Akdeniz’e göndermesi, Batı Avrupa'daki üslerde bulunan bazı Amerikan uçaklarının İncirlik’e getirilmesi ${ }^{100}$, gerilimi artırmıştır. Ağustos 1957 sonunda Ürdün ve Irak Kralları ile Türkiye Cumhurbaşkanı’nın İstanbul'da ABD Dışişleri Bakan Yardımcısı Loy Henderson ile bir araya gelmesi ise Nasır yanlısı Arap devletlerinde Batı'nın Suriye rejimini devirmeye çalıştığı iddialarını güçlendirmiştir. Henderson, İran Başbakanı Musaddık’’n düşürülmesindeki rolü nedeniyle Arap ülkeleri tarafından "darbeci" olarak nitelendirilmekteydi ${ }^{101}$. Bu sirada ABD Başkanı Eisenhower, Başbakan Menderes’e gönderdiği mesajda, Suriye’nin bir saldırısına karşı Türkiye, Irak ve Ürdün bu ülkeye askeri harekata girişmek zorunda kalırsa ABD’nin kendilerine derhal silah yardımı yapacağını bildirmişti ${ }^{102}$. Nitekim ABD, Eylül 1957'den itibaren Türkiye, Irak, Ürdün ve Lübnan’a silah göndermeye hız vermiş, Türkiye de Suriye sınırında yeni askeri manevralara başlamış, bu gelişmeler Mısır, Suriye ve Sovyetler Birliği'nde Suriye’yi işgal hareketinin başlangıcı olarak nitelendirilmiştir ${ }^{103}$.

98- Gönlübol vd., a.g.e., s.301.

99- Armaoğlu, 20.Yüzyıl..., s.507.

100-Sander, Türk-Amerikan..., s.217.

$101-$ A.g.e., s.217.

102- Armaoğlu, 20.Yüzyıl..., s.508.

103- Sander, Türk-Amerikan..., s.219. 
Sovyet Başbakanı'nın Türkiye’nin bir askeri hareketinin dünya savaşına yol açabileceği tehdidinde bulunması, Başbakan Menderes'in cevaben Suriye'nin muhtemelen başkaları tarafından kullanılabilecek bir silah deposu haline getirildiğini belirtmesi, Sovyet savaş gemilerinin Lazkiye’ye gelmesi ${ }^{104}$, gerginliği daha da arttırmıştır. Ekim başında bazı sınır olaylarının yaşanması üzerine Suriye, Türkiye’ye bir protesto notası vererek, Türkiye’nin Suriye sınırında kışkırtıcı faaliyetlerde bulunduğu, sınır boyunca askeri yığınak yaptığı, Suriye hava sahasını ihlal ettiği, Türk askerlerinin Suriyeli köylülere ateş açtığı, bazı köylüleri kaçırdığı iddialarında bulunmuş, Türkiye ise cevaben, ileri sürülen iddiaların ve Türkiye'den duyulan endişelerin yersiz olduğunu, sınırda alınan tedbirlerin yalnızca savunma amacına yönelik bulunduğunu bildirmiştir ${ }^{105}$. Ekim 1957'de Sovyet Komünist Partisi Birinci Sekreteri Kruşçev'in Ortadoğu'da yeni bir savaş tehlikesinden söz ederek Türkiye’nin Suriye’ye saldırmak üzere olduğunu, bu durumda Sovyetler Birliği'nin kayıtsız kalamayacağını açıklaması, bir başka açıklamasında da Henderson'ın ziyaretinin amacının bazı Arap devletleri ile Türkiye'yi Suriye'ye karşı harekete geçirmek olduğuna dair ellerinde kanıt bulunduğunu, Türkiye’nin ABD’ye çok uzak, Sovyetler Birliği’nin ise çok yakın olduğunu ve bir savaş durumunda Türkiye'nin çok fazla dayanamayacağını belirtmesi, tansiyonu iyice yükseltmiştir ${ }^{106}$. ABD Dışişleri Bakanlığı’nın da, "aradaki mesafeye rağmen" ABD’nin, dostu ve müttefiki olan Türkiye’ye karşı NATO içinde yüklendiği taahhütleri hafife alamayacağını açıklamasıyla ${ }^{107}$, sorun Ortadoğu bölgesini aşarak iki büyük devlet arasında güç ve kararlılık gösterisine dönüşmüştür. Bu arada Suudi Arabistan Kralı Suud, Suriye ile Türkiye arasında arabuluculuk teklifinde bulunmuş, teklifi Türkiye kabul ederken Suriye’nin önce kabul ettiği, sonra reddettiği duyurulmuştur. Suriye'nin tutumunda, Mısır'ın girişime tepki göstererek Kral Suud'u Amerikan ajanı olmakla suçlaması ve arabuluculuk önerisini ABD’nin isteğiyle yaptığını ileri sürmesi etkili olmuştur ${ }^{108}$. Bununla birlikte, Sovyetler Birliği ile Suriye’nin, konuyu BM’ye götürmesinden sonra ve müzakereler sırasında Endonezya’nın meselenin taraflar arasında görüşme yoluyla çözülmesi teklifinde bulunmasıyla sorun ikili düzeye çekilmiş ve taraflar arasındaki hava yumuşamaya başlamıştır. Kasım 1957'de Suriye'nin şikayetini geri çekmesiyle konunun BM’de tartışılması bitmiş, Türkiye de Suriye sınırına yığgdığı birlikleri çekmeye başlamıştır ${ }^{109}$. Krizin sona ermesinde Suriye ile Misır'ın Kasım 1957'de, 1 Şubat 1958 tarihinden itibaren Birleşik Arap Cumhuriyeti (BAC) adı altında birleşmeye karar vermesinin de rolü olmuştur ${ }^{110}$.

Süveyş Krizi'nden sonra Türkiye ile Irak’’n Nasır’’n gücünü kırmak için Suriye’deki rejimin değişmesinden yana bir tutum içinde olması ve Suriye krizi sırasında Türkiye ile Irak’ın bu ülkeye askeri müdahalede bulunabileceği iddialarının ortaya atılması, Nasır’ Suriye

104- Armaoğlu, 20.Yüzyıl..., s.508-509.

105- Gönlübol vd., a.g.e., s.303-304.

106-Sander, Türk-Amerikan..., s.220.

107- Armaoğlu, 20.Yüzyıl..., s.509.

108- Firat ve Kürkçüoğlu, a.g.m., s.631.

109- Sander, Türk-Amerikan..., s.222-223.

110- Armaoğlu, 20. Yüzyıl..., s.509. 
merkezli üstünlük mücadelesini kaybettiği takdirde, Arap dünyasındaki etkinliğini de yitirebileceği düşüncesine yöneltmiştir. Bu nedenle Mısır 13 Ekim 1957’de, 1955 tarihli Mısır-Suriye savunma işbirliği anlaşmasına dayanarak Lazkiye’ye asker göndermiştir ${ }^{111}$. Bundan bir ay sonra 18 Kasım 1957'de Misır Meclisi'nden bir grup Suriye'yi ziyaret ederek Suriyeli parlamenterlerle görüşmüş ve görüşmeler sonunda Mısır ve Suriye hükümetlerine iki ülke arasında federal birlik kurma çağrısında bulunulmasına karar verilmiştir ${ }^{112}$. Birleşme teklifinin arkasında komünistlerin Suriye'de giderek artan nüfuzundan endişe duyan Baasçılar bulunmaktadır.

Baas, kilit noktalarda bulunan komünistlerin, kendilerini bilahare iktidara getireceğini umdukları Sovyetler Birliği ile daha yakın ilişkiler kurulması taraftarı olduklarını, Komünist Partisi’nin, Baas’ın tek başına mücadele edemeyeceği kadar güçlendiğini değerlendirmiş ve komünistlerin aniden iktidara gelmesini engellemek için Misır ile birleşme fikrini ortaya atmıştır ${ }^{113}$. Türkiye, Suriye'nin Sovyetler Birliği'nden çok, o sırada Sovyetler Birliği’nin tam etkisi altında bulunmayan Mısır’a bağlanacağı anlaşıldığı için bu birleşmeden memnunluk duymuş ve BAC'1 11 Mart 1958'de resmen tanımıştır ${ }^{114}$. ABD de bu birleşmeyi Suriyede bir darbeyi önleyebileceği düşüncesiyle olumlu karşılayacaktır ${ }^{115}$. Aslında Suriye üzerinde Mısır/Nasır nüfuzunun kabul edilmek zorunda kalınması ironik bir durumdur. Sovyetler Birliği’nin bölgeye girmesini sağlayan bir ülke olarak görülen Mısır’n şimdi Sovyet nüfuzunu engelleyeceği düşünülmektedir.

BAC’ın kurulması Arap dünyasında dengeleri Mısır lehine değiştirmiş, Nasır’ın bölgesel etkinliğinin daha da artmasına neden olmuştur. Arap birliğinin yaratılması yolunda bir adım olarak görülen birleşme, Nasır’ın Arap dünyası üzerindeki öncü rolünü de pekiştirmiştir. Birleşme Nasır'dan çok Suriyeli Baasçıların isteğiyle gerçekleşmiş olsa da Nasır'ın çıkarlarına son derece uygun düşmüş, Nasır Suriye’ye hâkim olarak özellikle Irak’a karşı kuvvetli bir pozisyon elde etmiştir ${ }^{116}$. Nasır birleşme konusunda uzun süre tereddüt etmiş, ancak Suriye'nin komünistlerin kontrolüne girmesini önlemek için birleşmeyi kabul etmek durumunda kalmıştır ${ }^{117}$. Nitekim Nasır'ın, birleşmeden sonra Komünist Parti liderlerini sürgüne göndermek, Sovyet yanlısı subayları görevden uzaklaştırmak gibi uygulamaları Sovyetler Birliği'nde memnuniyetsizlik yaratmıştır ${ }^{118}$.

\subsubsection{Irak Rejiminin Devrilmesi ve Lübnan ile Ürdün'e Yönelik Müdahaleler}

Nasır’’n bölgede güçlenmesi Batı yanlısı Irak, Ürdün ve Lübnan yönetimlerinde endişe uyandırmış, Suriye ile Mısır’ın birleşmesini rejimleri için tehdit olarak gören Irak ve

111- Duman, a.g.m., s.330.

112- Gönlübol vd., a.g.e., s.305.

113- Kamel Abu Jaber, Arap Baas Sosyalist Partisi, Altınok Matbaas1, Ankara, 1970, s.55.

114- Gönlübol vd., a.g.e., s.311.

115-Sander, Türk-Amerikan..., s.224.

116- Duman, a.g.m., s.330.

117-Armaoğlu, 20.Yüzyıl..., s.509.

118- Erdem, a.g.m., s.83. 
Ürdün, 14 Şubat 1958'de Birleşik Arap Krallığı adı altında birleşme kararı almıştır. Birleşme kararı Mısır’ın sert tepkisiyle karşılaştığ 1 gibi, Iraklı milliyetçilerin de tepkisini çekmiş, ülkede birleşme aleyhine gösteriler düzenlenmeye başlamıştır. Bu süreç, 14 Temmuz 1958'de General Abdülkerim Kasım liderliğindeki askeri darbeyle ve monarşinin yıkılıp cumhuriyet idaresinin kurulmasıyla sonlanacaktır. Darbe sırasında Kral II. Faysal, Kral Naibi Abdülillah ve Başbakan Nuri Sait Paşa öldürülmüştür. Irak’taki darbe Batı'da büyük endişeyle karşılanmış, ABD, güçlü bir karşılık verilmediği takdirde bu gelişmenin Batı́nın Ortadoğu'dan tasfiyesiyle sonuçlanabileceğini düşünmüştür ${ }^{119}$. Bundan dolayı Irak darbesinden bir gün sonra, 15 Temmuz 1958'de ABD deniz piyadeleri Lübnan'a çıkarılmış, bunu İngiliz paraşüt birliklerinin Ürdün’e gönderilmesi izlemiştir.

Lübnan'da Haziran 1957 seçimlerinden itibaren Cumhurbaşkanı Camille Chamoun ile Nasır'a yakın milliyetçiler arasında anlaşmazlıklar yaşanmaktaydı. Chamoun'un anayasaya aykırı olduğu halde bir dönem daha işbaşında kalmak istemesi ve buna uygun anayasa değişikliğini gerçekleştirecek bir parlamentonun seçilmesi için seçimlere hile karıştırması ülkede hoşnutsuzluk yaratmıştı. Mayıs 1958'de muhalif bir gazetecinin öldürülmesi üzerine cinayetin hükümet tarafından düzenlendiğini ileri süren Nasırcıların başlattığı grev ve gösteriler ayaklanmaya dönüşmüş, milliyetçiler ile Batı yanlıları arasında silahlı çatışmalar çıkmıştır ${ }^{120}$. Çatışmalar üzerine Chamoun, ABD, Fransa ve İngiltere'den yardım istemesinin yanı sıra, asilerin Nasır tarafından kışkırtılıp desteklendiğini, Suriye'den Lübnan'a kitleler halinde sızmalar olduğunu ileri sürerek 22 Mayıs 1958'de BM Güvenlik Konseyi’ne başvurmuştur. Güvenlik Konseyi’nin görevlendirdiği gözlemciler heyeti Temmuz başında hazırladığı raporda Lübnan’ın iddia ettiği tarzda bir sızmaya rastlanmadığını, ancak tahkikata devam edildiğini rapor etmişse de $A B D$, Irak'taki darbe üzerine Lübnan'a asker gönderme kararı almıştır ${ }^{121}$. Lübnan'a Amerikan deniz piyadelerinin çıkarılmasından bir gün sonra da Ürdün Kralı Hüseyin, ABD ve İngiltere'den Ürdün'e askeri yardım yapılmasını istemiş ve 17-18 Kasım 1958 tarihlerinde Kıbrıs'ta üslenmiş İngiliz paraşütçü alayı Ürdün'e indirilmiştir ${ }^{122}$. Bağdat Paktı ülkeleri Lübnan ve Ürdün'e asker gönderilmesini desteklerken, Sovyetler Birliği Arap ülkelerinin içişlerine silahlı müdahale olarak nitelendirdiği bu hareketleri şiddetle kınamış ve Amerikan ve İngiliz askerlerinin derhal bu iki ülkeden çekilmesini istemiştir. BM Genel Kurulu'nda Ürdün, Lübnan ve BAC’’n da aralarında olduğu Arap devletleri tarafından yapılan teklifin 21 Ağustos 1958'de kabul edilmesiyle Amerikan ve İngiliz askerlerinin bu ülkelerden peyderpey çekilmesi sağlanmıştır ${ }^{123}$.

Lübnan ve Ürdün'e asker gönderilmesi, 14 Temmuz darbesinin Batı’da yarattı̆̆ hatta paniğin bir sonucuydu. Suriye'de komünist nüfuzu Batı tarafından önlenemez ve bu ülke Nasır’a “teslim edilirken”, Batı'ya en yakın ülkelerden biri olan Irak’ta monarşinin

119- Armaoğlu, 20. Yüzyıl..., s.512.

120- A.g.e., s.510.

121- Haluk Ülman, “Orta Doğu Buhranı”, Ankara Üniversitesi SBF Dergisi, C.13, S.4, 1958, s.242.

122- A.g.m., s.243.

123-A.g.m., s.250-251. 
yıkılması, Batı’nın bölgedeki prestijine ağır bir darbe olarak görülmüş, Lübnan ve Ürdün'de de aynı durumun ortaya çıkmaması için harekete geçilmiştir. Irak monarşisinin yıkılması, Türkiye’nin bölgedeki en yakın müttefiklerinden birini kaybetmesi anlamına gelmekteydi. Dolayısıyla 17 Temmuz 1958'de ABD’ye başvurup Irak’a müdahaleye kararlı olduğunu bildirmiş, bu yüzden Türkiye ile Sovyetler Birliği arasında kısa süreli bir gerginlik de yaşanmıştır ${ }^{124}$. Menderes Hükümeti, darbeyi dünya barışına ve güvenliğine ve Bağdat Paktı'na yöneltilmiş bir hareket olarak görmüş, dışarıdan teşvik edilen yıkıcı faaliyetlerin neticesi olduğunu düşünmüştür. Darbeyi gerçekleştiren "siyaset eşkiyalarının” Ortadoğu'da önemli bir barış ve istikrar unsuru olan Bağdat Paktı'nı da vurmak istedikleri, darbenin İstanbul'daki Bağdat Paktı toplantısı ile aynı gün yapılmış olmasının bu niyeti gösterdiği belirtilmiştir ${ }^{125}$. Türkiye bu çerçevede darbe yönetiminin meşruiyetini de sorgulamış, ancak daha sonra tutumunu yumuşatarak 31 Temmuz 1958'de yeni Irak hükümetini tanımıştır ${ }^{126}$. Kasım Yönetimi darbeyi gerçekleştirdiğinde Irak’ın çıkarlarıyla ters düşmeyen uluslararası taahhütlerine bağlı kalacağını açıklamış olmakla birlikte, Bağdat Paktı'nın Batı karşıtı ve milliyetçi çevrelerde yarattığı tepki, hatta monarşinin yıkılmasında Bağdat Paktı́nın etkili olduğu yorumları dikkate alındığında, Pakt'tan çıkması beklenen bir gelişmeydi. Nitekim Irak, 24 Mart 1959'da Pakt’tan çekilmiş ve Bağdat Paktı, Merkezi Antlaşma Teşkilatı (CENTO) adını alarak bir süre daha mevcudiyetini sürdürmüştür.

14 Temmuz darbesi, öncelikle Menderes Hükümeti’nin en önemli dış politik yatırımlarından birisi olan Bağdat Paktının çöküşünü simgelemekteydi. Türkiye’nin Ortadoğu politikasının temel taşı niteliğindeki, kurulması ve yaşaması için büyük çaba harcadığı bir bölgesel güvenlik örgütünün en önemli halkası böylelikle devre dışı kaliyordu ${ }^{127}$.

\section{SONUÇ}

Diplomatik ilişkilerin kurulduğu 1926'dan itibaren inişli çıkışlı bir seyir izleyen TürkiyeMısır ilişkileri, 1935'te İtalya’nın Habeşistan’ı işgali üzerine Kızıldeniz ve Akdeniz’de ortaya çıkan ortak İtalya tehdidi nedeniyle İkinci Dünya Savaşı'na kadar devam eden yumuşama döneminin ardından savaş sonrasının değişen koşulları çerçevesinde farklı tehditlerin yol açtı̆̆ 1 farklı, hatta zıt dış politik tercihlerden kaynaklanan bir ayrışma sürecine girmiştir.

İkinci Dünya Savaşı’nın bitmesinden itibaren Mısır için İngiltere’nin ülkesindeki askeri mevcudiyetine son vermek ve böylece tam bağımsızlı̆̆ını sağlamak başlıca mesele durumundadır. Türkiye bu dönemde Sovyet tehditleri karşısında İngiltere ve ABD'den destek arayışındadır. İngiltere Sovyetlerin Akdeniz ve Ortadoğu’ya inmeyi amaçladığını düşünmekte, bu nedenle bölgedeki çıkarlarını korumayı amaçlamakta, Mısır'dan çıkmayı

124- Armaoğlu, 20.Yüzyıl..., s.513.

125- Ülman, a.g.m., s.257.

126- A.g.m., s.258-259

127- Özcan, a.g.e., s.21. 
düşünmemektedir. Bu nedenle İngiltere stratejik konumunu da dikkate alarak, bölgede kalmasını sağlayacak bölgesel savunma düzeninde Türkiye’nin yer almasını istemekte, Türkiye ise bunu NATO’ya girişinin bir adımı olarak değerlendirmektedir. Türkiye’nin Süveyş’teki İngiliz askeri mevcudiyetini Sovyet tehdidinin önlenmesi açısından gerekli görmesi ve sadece güvenlik perspektifinden değerlendirmesi, meseleyi ulusal bağımsızlık ve egemenlik sorunu olarak gören Misır ile daha 1946'da ters düşmesine neden olacaktır. 1948'de İsrail devletinin kuruluşu Ortadoğu'da bir dönüm noktası olmuştur. İsrail'i yok etmeyi amaçlayan Arapların ağır yenilgisi yönetimlerin değişmesine, milliyetçiliğin güçlenmesine, Batı karşıtlı̆̆ının artmasına yol açmıştır. 1952 Mısır darbesinin lideri Nasır, karizmatik kişiliği, Batı emperyalizmini hedefleyen tutumu, İsrail’e karşı mücadele kararlılığıyla Arap dünyasında etkisini arttırmakta, Arap kitlelerini peşinden sürüklemektedir. Süveyş Krizi’nde Batılılara boyun eğmemesi tam bir Arap kahramanı olmasını sağlamıştır. Ancak Türkiye; Nasır’’n, yıllarca tahakkümü altında kaldıkları Batı'ya karşı çıkışının, Filistinlileri yurtlarından atan ve Batılıların koruması altında kurulan İsrail'in bölgeden silinmesini istemesinin, Batının tekelini kırarak Sovyetler Birliği’nden silah almasının Araplar açısından ne ifade ettiğini anlamaya çalışmamıştır. Nasır'ı saldırgan, kışkırtıcı, Sovyet emellerine hizmet eden bir figür olarak görmüştür. Nasır’ın Bağdat Paktı'nın Arapların tehdit algılamadı̆̆ı Sovyetler Birliği’ne karşı kurulmasını gerçekçi bulmaması, İsrail’e karşı Arap birliğini bozacağını düşünmesi ve Batı emperyalizminin bölgedeki mevcudiyetini uzatacağ diğer Arap devletlerinin Pakt’a katılmasını sağlamaya çalışması, Eisenhower Doktrini’ni desteklemesi, Ürdün ve Lübnan bunalımlarında Nasır karşıtlarına destek vermesi, Irak ile birlikte Batı karşıtı devletlere müdahale niyetini ortaya koyması, Mısır’n Arap liderliği mücadelesindeki ana rakibi Irak ile yakın ilişkileri, Türkiye ile Mısır arasında 1955'ten itibaren hız kazanan mücadelenin başlıca göstergeleridir. 1955-1960 arasındaki dönemde bölgede sürekli olarak Mısır ile karşı karşıya gelen Türkiye’nin Ortadoğu politikasının Nasır ile mücadele çerçevesinde şekillendiğini söylemek yanlış olmayacaktır.

1958'de, Irak'ta gerçekleştirilen rejim değişikliği, Sovyetlere karşı Araplara dayanan bir savunma anlayışının "Araplara rağmen" sürdürülemeyeceğini ortaya koymuştur. Bu aslında Nasır’’n bir başarısıdır. İsrail’in tehdit olarak görüldügüu, Batı karşıtlığının güçlü olduğu bölgede Sovyet tehdidine karşı ittifak arayışlarının sürdürülmesi Sovyetlerin bölgeye girişine hizmet etmekten başka bir sonuç yaratmamıştır. Bölgedeki gelişmelerin Soğuk Savaş perspektifinden değerlendirilmesinin ve izlenen hatalı politikaların Türkiye’yi bölgede ve uluslararası alanda yalnız bıraktı̆̆ı kısa sürede anlaşılacak ve Arap ülkelerinin sorunlarına karşı daha duyarlı bir yaklaşım benimsenecekse de Türkiye'nin bu dönemde bölgede yarattığı imajı düzeltmek kolay olmayacaktır. 


\section{KAYNAKÇA}

ABU RUMMAN, Mohamed, Ürdün'de 1989-2005 Arası Demokratik Dönüşüm, Yayınlanmamış Doktora Tezi, Ankara Üniversitesi Sosyal Bilimler Enstitüsü Kamu Yönetimi ve Siyaset Bilimi Ana Dalı, Ankara, 2009.

ABU JABER, Kamel, Arap Baas Sosyalist Partisi, Altınok Matbaası, Ankara, 1970.

ARI, Tayyar, Geçmişten Günümüze Ortadoğu. Siyaset, Savaşve Diplomasi, Cilt I, MKM Yayınları, Bursa, 2012.

ARMAOĞLU, Fahir, 20. Yüzyıl Siyasi Tarihi (1914-1990) Cilt I: 1914-1980, Türkiye İş Bankası Yayınları, Ankara, 1991.

ARMAOĞLU, Fahir, Filistin Meselesi ve Arap-İsrail Savaşları, Türkiye İş Bankası Yayınları, Ankara, b.t.y.

ARMAOĞLU, Fahir, Türk Amerikan İlişkileri 1919-1997, Kronik Kitap, İstanbul, 2017.

ATABAY, Mithat, Son Yüzyılda Türkiye ve Ortadoğu, Paradigma Akademi Yayınları, Çanakkale, 2016.

AYDIN, Mustafa, "Determinants of Turkish Foreign Policy: Changing Patterns and Conjunctures during the Cold War”, Middle Eastern Sudies, C.36, S.1, Ocak 2000, ss.103-139.

BİLGIN, Mustafa Sttk1, "British Attitude Towards Turkey's Policies in the Middle East (1945-47)", Turkish Yearbook of International Relations, C.33, 2002, ss.257-269.

BULUT, Semih, “Atatürk Dönemi Türkiye-Mısır İlişkileri ve Günümüze Etkileri”, Atatürk Araştırma Merkezi Dergisi, C.XXVI, S.78, Kasim 2010, ss.535-559.

ClEVElAND, L. William, Modern Ortadoğu Tarihi, (Çev. Mehmet Harmancı), Agora Kitaplığı, İstanbul, 2015.

ÇAKIRBAŞ, Ali, "Amerikan Perspektifinden 1957 Krizine Giden Süreçte Suriyede Komünizmin Yükselişi”, History Studies, C.10, S.6, Eylül 2018, ss.33-43.

ÇELİK, Mustafa Edip, “İkinci Dünya Savaşı Bitiminden Bağdat Paktı’na Geçen Süreçte Türkiye’nin Ortadoğu Politikası", Türkiyat Araştırmaları Dergisi, TAED-64, Ocak 2019, ss.475-497.

DUMAN, Sabit, “Ortadoğu Krizleri ve Türkiye”, Ankara Üniversitesi Türk İnkılap Tarihi Enstitüsü Atatürk Yolu Dergisi, S.35-36, Mayı-Kasım 2005, ss.313-332.

ERDEM, Gökhan, “Bağlantısızlıktan Bağımlılığa: Nasır Döneminde Mısır-SSCB İlişkileri”, Turkish Yearbook of International Relations, C.48, 2017, ss.69-98.

FIRAT, Melek-KÜRKÇÜOĞLU, Ömer, “Arap Devletleriyle İlişkiler”, Baskın Oran (ed.), Türk Dış Politikası. Kurtuluş Savaşından Bugüne Olgular, Belgeler, Yorumlar, Cilt I: 1919-1980, İletişim Yayınları, İstanbul, 2009, ss.615-635.

GÖNLÜBOL, Mehmet-ÜLMAN, Haluk, “Türk Dış Politikasının Yirmi Yılı 1945-1965”, Ankara Üniversitesi SBF Dergisi, C.21, S.1, 1966, ss.143-182.

GÖNLÜBOL, Mehmet- SAR, Cem- ESMER, Ahmet Şükrü- SANDER, Oral- ÜLMAN, Haluk- BİLGE, SuatSEZER, Duygu- KÜRKÇÜOĞLU, Ömer, Olaylarla Türk Dış Politikası (1919-1973),Ankara Üniversitesi Siyasal Bilgiler Fakültesi Yayınları, Ankara, 1982.

GÜRÜN, Kamuran, Dış İlişkiler ve Türk Politikası (1939'dan Günümüze), Ankara Üniversitesi Siyasal Bilgiler Fakültesi Yayınları, Ankara, 1983. 
KHOURI, Fred, J., The Arab-Israeli Dilemma, Syracuse University Press, New York, 1985.

KÜÇÜKVATAN, Mahir, “Soğuk Savaşın Türk Dış Politikasına Etkileri ve 1957 Türkiye-Suriye Bunalımı”, Çağdaş Türkiye Tarihi Araştırmaları Dergisi, C.XI, S.23, Güz 2011, ss.73-91.

KÜRKÇÜOĞLU, Ömer, "An Analysis of Turkish-Arab Relations”, Ankara Üniversitesi SBF Dergisi, C.27, S.1, 1972, ss.117-134.

ÖZCAN, Gencer, “Türkiye İsrail İlişkilerinde Dönüşüm: Güvenliğin Ötesi”, TESEV Dış Politika Analiz Serisi 1”, Kasım 2005, tesev.org.tr./wp-content-uploads/2015/11/Turkiye_Israil_Iliskilerinde_Donusum.pdf, (Erişim: 05.08.2019).

SANDER, Oral, Türkiye’nin Dış Politikası,İmge Kitabevi Yayınları, Ankara, 1998.

SANDER, Oral, Türk-Amerikan İlişkileri 1947-1964, İmge Kitabevi Yayınları, Ankara, 2016.

SARIKOYUNCU DEĞERLİ, Esra, “Türk-Mısır Siyasi ve Kültürel İlişkileri (1923-1938)”, Yeni Türkiye, Ortadoğu Özel Sayısı, C.V, S. 86, Ocak-Haziran 2016, ss.23-37.

SHLAIM, Avi, Lion of Jordan. The Life of King Hussein in War and Peace, Penguin Books, London, 2007.

ŞİMŞİR, Bilal, "Fes Olayı: Türkiye-Mısır İlişkilerinden Bir Sayfa (1932-1933)”, TTK Belleten, C.48, S.189-190, Ocak-Nisan 1984, ss.1-87.

T.C. Dışişleri Bakanlığı Araştırma ve Siyaset Planlama Genel Müdürlüğü, Türkiye Dış Politikasında 50 Yıl. İkinci Dünya Savaşı Yılları (1939-1946), Ankara, 1973.

TÜR, Özlem, “Türkiye ve Filistin (1908-1948) : Milliyetçilik, Ulusal Çıkar ve Batılılaşma”, Ankara Üniversitesi SBF Dergisi, C.62, S.1, 2007, ss.223-251.

TÜRKMEN, İlter, “Türkiye Cumhuriyeti’nin Ortadoğu Politikası”, BİLGESAM, 17 Temmuz 2014, www. bilgesam.org/images/dokumanlar/0-22-20140717111.pdf, (Erişim: 05.08.2019).

UZER, Umut-UZER, Ayşe, "Diverging Perceptions of the Cold War: Baghdad Pact as a Source of Conflict Between Turkey and the Nationalist Arab Countries", Turkish Yearbook of International Relations, C.36, 2005, ss.101-118.

ÜLMAN, Haluk, “Orta Doğu Buhranı”, Ankara Üniversitesi SBF Dergisi, C.13, S.4, 1958, ss.232-261.

ÜLMAN, Haluk, “Türk Dış Politikasına Yön Veren Etkenler I (1923-1968)”, Ankara Üniversitesi SBF Dergisi, C.23, S.23, 1968, ss.241-273.

ÜLMAN, Haluk-SANDER, Oral, “Türk Dış Politikasına Yön Veren Etkenler: 1923-68 II”, Ankara Üniversitesi SBF Dergisi, C.27, S.1, 1972, ss.1-24. 